\title{
Andean shortening, inversion and exhumation associated with thin- and thick-skinned deformation in southern Peru
}

\author{
NICHOLAS D. PEREZ*††, BRIAN K. HORTON*, NADINE MCQUARRIE§, \\ KONSTANZE STÜBNERף \& TODD A. EHLERS
}

*Institute for Geophysics and Department of Geological Sciences, Jackson School of Geosciences, University of Texas at Austin, Austin, TX 78712, USA

$\ddagger$ Department of Geology and Geophysics, College of Geosciences, Texas A\&M University, College Station, TX, 77843-3115, USA

$\S$ Department of Geology and Planetary Science, University of Pittsburgh, Pittsburgh, Pennsylvania, USA

qDepartment of Geoscience, University of Tübingen, Tübingen, Germany

(Received 30 October 2015; accepted 30 January 2016; first published online 3 June 2016)

\begin{abstract}
A balanced cross-section spanning the Eastern Cordillera and Subandean Zone of southern Peru $\left(13-15^{\circ} \mathrm{S}\right)$ constrains $\sim 130 \mathrm{~km}(38 \%)$ of Cenozoic orogen-normal SW-NE Andean deformation accommodated by thick- and thin-skinned retro-arc fold-thrust belt shortening that overprinted preAndean Triassic normal faults. Zircon and apatite (U-Th)/He ages demonstrate continuous Oligocene to Miocene cooling of the Permo-Triassic Coasa pluton in the Eastern Cordillera. Zircon (U-Th)/He ages $(\sim 34-18 \mathrm{Ma})$ are reset and define a steep age versus elevation relationship. Apatite (U-Th)/He results reveal reset ages that define two spatially separated groups with ages of $\sim 30-26 \mathrm{Ma}$ and $\sim 17-$ $11 \mathrm{Ma}$. Detrital zircon U-Pb geochronologic results from Cretaceous-Cenozoic siliciclastic rocks from the Altiplano/Eastern Cordillera record Andean fold-thrust belt and magmatic-arc sediment sources. Correlative Subandean Zone rocks preserve a cratonic sediment contribution, with minor Andean sediment appearing in some Cenozoic rocks. We propose that earliest Andean deformation and structural compartmentalization of the Eastern Cordillera was linked to selective inversion of inherited Permo-Triassic basement-involved normal faults that guided subsequent thick- and thinskinned deformation. Provenance variations between the hinterland and foreland depocentres reveal competing eastern and western sediment sources, reflecting an axial zone in the Eastern Cordillera that coincided with the inherited Triassic graben and impeded sediment source mixing. Our zircon and apatite $(\mathrm{U}-\mathrm{Th}) / \mathrm{He}$ ages are consistent with published constraints along strike and support pulses of Eocene to late Miocene exhumation that were likely driven by normal fault reactivation and protracted Eastern Cordillera deformation.
\end{abstract}

Keywords: Altiplano, Andes, fold-thrust belts, Peru, inversion.

\section{Introduction}

Inversion of inherited structures is a fundamental process in many contractional orogenic belts (Butler, 1989; Williams et al. 1989; Marshak, Karlstrom \& Timmons, 2000, Butler, Tavarnelli \& Grasso, 2006; Mouthereau \& Lacombe, 2006). Evidence for inversion is present in the northern Andes (Cooper et al. 1995; Mora et al. 2006) and southern Andes (Ramos et al. 2004; Giambiagi et al. 2011; Mescua et al. 2014), but is limited in the highly shortened central Andes. In the $>3 \mathrm{~km}$ high Central Andean Plateau (CAP), defined as a $\sim 1500 \times$ $300 \mathrm{~km}$ region spanning southern Peru, Bolivia, and northern Argentina (Isacks, 1988), numerous studies provide insights into the geologic framework (shortening magnitude, structural geometries, fault timing, foreland basin histories, exhumation patterns) (Roeder, 1988; Sheffels, 1990; Sempere et al. 1990; Gubbels,

†Author for correspondence: ndperez@tamu.edu

†urrent Address: Department of Geology and Geophysics, College of Geosciences, Texas A\&M University, College Station, TX, 77843-3115, USA
Isacks \& Farrar, 1993; Allmendinger et al. 1997; Baby et al. 1997; Lamb \& Hoke, 1997; Horton, Hampton \& Waanders, 2001; Horton et al. 2002; McQuarrie, 2002a; DeCelles \& Horton, 2003; McQuarrie et al. 2005; Oncken et al. 2006; Barnes et al. 2006; Gillis, Horton \& Grove, 2006), geophysical models of crust and lithosphere architecture (Whitman et al. 1992; Schmitz, 1994; Wigger et al. 1994; Beck et al. 1995; Whitman, Isacks \& Kay, 1996; Myers et al. 1998; Beck \& Zandt, 2002) and palaeoaltimetry history (Garzione et al. 2006, 2008, 2014; Ghosh, Garzione \& Eiler, 2006; Leier et al. 2013; Saylor \& Horton, 2014). Despite these advances, debate persists regarding the timing of surface uplift, the role of crustal thickening on plateau and topographic development, and how inherited structural architecture may contribute to the tectonic and magmatic evolution of the Cenozoic Andean orogeny (e.g. Allmendinger, 1986; Ehlers \& Poulsen, 2009; Fiorella et al. 2015).

Along-strike variations in structural style have been attributed to changes in pre-orogenic sedimentary basin distribution and architecture (Allmendinger et al. 1983; 
Allmendinger \& Gubbels, 1996; McQuarrie, 2002b), changes in the geometry of the subducting Nazca slab (Barazangi \& Isacks, 1976; Cahill \& Isacks, 1992), spatial variations in climate and basin integration (Horton, 1998, 1999; Riller \& Oncken, 2003; Strecker et al. 2007), the role of along-strike motion of material potentially by lower crustal flow (Hindle et al. 2005; Arriagada et al. 2008; Eichelberger \& McQuarrie, 2015), the inherited structural framework from pre-Andean deformation (Ramos, Cegarra \& Cristallini, 1996; Kley \& Monaldi, 1998; Mouthereau, Watts \& Burov, 2013) and rheological, strength, and temperature changes of the crust and lithosphere (Watts et al. 1995; Babeyko \& Sobolev, 2005). Previous balanced cross-sections have focused more on the central (Bolivia) and southern (Argentina) segments (Allmendinger et al. 1990; Grier, Salfity \& Allmendinger, 1991; Dunn, Hartshorn \& Hartshorn, 1995; Kley, 1996; Baby et al. 1997; Kley, Monaldi \& Salfity, 1999; Kley \& Monaldi, 2002; McQuarrie, 2002a; Müller, Kley \& Jacobshagen, 2002; Elger, Oncken \& Glodny, 2005; Kley et al. 2005; McQuarrie, Barnes \& Ehlers, 2008; Menichetti, Lodolo \& Tassone, 2008; Monaldi, Salfity \& Kley, 2008; Giambiagi et al. 2011; Sagripanti et al. 2012; Pearson et al. 2013; Mescua et al. 2014), than the northern (Peruvian) segment (W. F. Gil Rodriguez, unpub. Ph.D. thesis, Univ. Paul Sabatier, 2001; Gil Rodriguez, Baby \& Ballard, 2001; Gotberg, McQuarrie \& Carlotto 2010; Espurt et al. 2011; Scherrenberg, Holcombe \& Rosenbaum, 2014; Eude et al. 2015). In the Bolivian CAP, cross-section reconstructions emphasize thin-skinned deformation with minimal reactivation of pre-existing structures. In contrast, segments of the southern Andes in Argentina and the northern Andes of northern Peru, Ecuador and Colombia (Cooper et al. 1995; PARSEP, 2000; Hermoza et al. 2005; Mora et al. 2006; Bayona et al. 2008; Baby et al. 2013; Eude et al. 2015) have been recognized as zones wherein pre-existing extensional structures (e.g. Salta rift system) exert an important influence on later Andean shortening. The role of inherited lithospheric strength may also have an important role on the style and magnitude of deformation. Higher effective elastic thicknesses (Te) correlate with higher shortening magnitudes in the Central Andes of Bolivia, whereas Te and shortening magnitudes are lower in parts of Peru, Colombia and the Sierras Pampeanas of Argentina (Watts et al. 1995; Mouthereau, Watts \& Burov, 2013), potentially owing to the magnitude and orientation of pre-existing faults. Recent syntheses highlight numerous pre-Cenozoic extensional structures along much of the Andean orogen, but a paucity of normal faults in southern Peru and Bolivia (McGroder, Lease \& Pearson, 2015) despite a proposed Permo-Triassic rift system in this part of the central Andes (Sempere et al. 2002). Identifying the location and potential selective reactivation of inherited structures is key to defining lateral variations in structural style, magnitude of deformation and the kinematic links between well-documented segments of the Andean chain (Mpodozis \& Ramos, 1989; Kley \& Monaldi, 1998; Kley, Monaldi \& Salfity, 1999).
The proliferation of thermochronologic datasets affords the opportunity to constrain kinematic models of fold-thrust evolution. Conflicting interpretations support either in-sequence thrust activation (McQuarrie et al. 2005; Barnes et al. 2006, 2008) or synchronous deformation across broad zones of the CAP (Elger, Oncken \& Glodny, 2005; Oncken et al. 2006; Ege et al. 2007). Existing exhumational records suggest Eocene and younger development of the Eastern Cordillera in southern Peru and Bolivia (Benjamin, Johnson \& Naeser, 1987; Farrar et al. 1988; Kontak et al. 1990; Gillis, Horton \& Grove, 2006), with deformation propagating to the Subandean Zone after $\sim 25-20 \mathrm{Ma}$ (Horton, 2005; Barnes et al. 2006, 2008; Espurt et al. 2011; Eude et al. 2015). Thermochronologic results show $\sim 13-7$ Ma canyon incision linked to uplift along the western CAP margin (Schildgen et al. 2007, 2009; Gunnell et al. 2010) and Pliocene canyon incision linked to enhanced climatedriven erosion along the eastern CAP margin (Lease \& Ehlers, 2013). Across the central Andes, geomorphologic and thermochronologic investigations suggest Miocene and younger exhumation driven by a complex interplay between tectonically and climatically controlled erosional processes (Strecker et al. 2009; Barnes et al. 2012; Whipple \& Gasparini, 2014).

Cenozoic hinterland and foreland basins are well preserved in the elevated orogenic interior and flanking lowland regions between the mountain belt and South American craton (Jordan, 1995; Horton, 2012). Ongoing debates focus on whether these depocentres reflect isolated long-lived basin systems or were once contiguous, then later partitioned by uplift of the Eastern Cordillera (e.g. Cooper et al. 1995; Horton, 2005; Mortimer et al. 2007; Horton et al. 2010, 2015; Moreno et al. 2011; Siks \& Horton, 2011; Saylor et al. 2012; Pingel et al. 2013; Perez \& Horton, 2014). In central and northern Peru, the existence of a long-lived structural high along the Eastern Cordillera ('Marañon High' or 'Marañon Geanticline', separating the East and West Peruvian Troughs) has been proposed to explain observed stratigraphic relationships between the separated hinterland and foreland basins (BenavidesCaceres, 1956; Wilson, 1963; Mégard, 1978, 1984; Dalmayrac, Laubacher \& Marocco, 1980; BenavidesCaceres, 1999; Jaillard, Bengtson \& Dhondt, 2005). In the Eastern Cordillera of Bolivia, Eocene exhumation has been interpreted as the initial partitioning of a oncecontinuous foreland basin system (DeCelles \& Horton, 2003; McQuarrie et al. 2005). Resolution of this issue has implications for palaeogeographic reconstructions, and testing the genetic links between flexural foreland/hinterland basin evolution and fold-thrust belts.

This regional study at $13-15^{\circ} \mathrm{S}$ in southern Peru presents new estimates of total shortening across the Eastern Cordillera and Subandean Zone constrained by a regional balanced cross-section and the timing of exhumational cooling from parts of the Subandean Zone and Eastern Cordillera from apatite and zircon (U-Th)/He thermochronology. We also identify major pre-Andean normal faults selectively reactivated 
during Cenozoic orogenesis and use U-Pb detrital zircon geochronology to establish the Cretaceous through Cenozoic provenance record of the Altiplano and Subandean basins. These data provide insights into the geometry, timing and kinematics of Cenozoic deformation in southern Peru, the role of inherited structural and stratigraphic architectures on strain and kinematics, and the long-term evolution of major Andean depocentres.

\section{Background}

\section{2.a. Tectonic framework}

In southern Peru, along the northern limb of the Bolivian Orocline, the dominant WNW-ESE structural grain departs from the $\mathrm{N}-\mathrm{S}$ strike that characterizes much of the Andes. The Altiplano is a high-elevation, low-relief plateau between the Western Cordillera (a Neogene magmatic arc) and Eastern Cordillera (an exhumed fold-thrust belt composed of PalaeozoicMesozoic strata) (Fig. 1a). Further inboard, the Subandean Zone (thin-skinned frontal thrust belt composed of Mesozoic-Cenozoic strata) defines the deformation front and border with the active foreland basin. The structural boundary between the Altiplano and Eastern Cordillera is defined by the NE-dipping Ayaviri fault (Fig. 1a), part of a larger fault system that persists $\sim 400 \mathrm{~km}$ along strike from $14^{\circ}$ to $18^{\circ} \mathrm{S}$ (Sempere et al. 1990; Perez \& Horton, 2014). The Eastern Cordillera-Subandean boundary is marked by the Main Andean Thrust, which places Ordovician on Cretaceous-Cenozoic rocks. Exposed faults are all brittle structures and no ductile shear zones were observed along this transect.

The Eastern Cordillera is a doubly vergent thrust wedge that is composed of three structural domains, each $\sim 50-60 \mathrm{~km}$ wide, and defined by abrupt changes in structural/stratigraphic exposure levels (Fig. 1b). (1) The Central Andean Backthrust Belt (CABB) (McQuarrie \& DeCelles, 2001) is a SW-verging system of thrust faults and folds in southern Peru and Bolivia, where it is also known as the Huarina fold-thrust belt (Sempere et al. 1990). Although most CABB exposures in southern Peru consist of Cretaceous sandstones, siltstones and limestones, lower Palaeozoic structural levels are exposed in Bolivia. (2) The Macusani structural zone, previously referred to as the Precordillera de Carabaya (Kontak et al. 1990; Sandeman et al. 1997) or 'Late Hercynian' fold domain (Laubacher, 1978), is distinguished by an abrupt increase in exposed structural levels $(>4 \mathrm{~km})$ relative to the $\mathrm{CABB}$, and oblique orientations of faults and folds in CarboniferousPermian strata relative to the main Andean trends. These features have been attributed to late Palaeozoic ('Late Hercynian') deformation (Mégard et al. 1971; Laubacher, 1978; Dalmayrac, Laubacher \& Marocco, 1980; Clark et al. 1990). (3) The Cordillera de Carabaya (McBride, Robertson \& Clark, 1983; Clark et al. 1990; Sandeman, Clark \& Farrar, 1995) is defined by a suite of Permo-Triassic plutons (Kontak et al. 1990;
Mišković et al. 2009) that hold up the topographic crest (up to $5500 \mathrm{~m}$ ) of the Eastern Cordillera. To the northeast, Ordovician-Devonian rocks mark another discrete increase in exposed structural levels and the transition to the frontal segment of the Eastern Cordillera.

Much of the Phanerozoic stratigraphic record is preserved in the $\sim 16 \mathrm{~km}$ thick succession of the Eastern Cordillera (Laubacher, 1978; Reimann Zumsprekel et al. 2015). In southern Peru, most of this succession is defined by marine Ordovician to Devonian siliciclastic deposits $(\sim 7 \mathrm{~km})$ and CarboniferousPermian marine clastic and carbonate rocks $(\sim 4 \mathrm{~km})$. A Triassic succession ( $>2 \mathrm{~km}$ ), the Mitu Group, preserves non-marine conglomerate, volcanic and siliciclastic rocks interpreted as synrift deposits (Noble et al. 1978; Dewey, 1988; Rosas, Fontbote \& Tankard, 2007; Ramos, 2009; Reitsma, 2012; McGroder, Lease \& Pearson, 2015). Jurassic rocks are absent, but a Cretaceous section $(\sim 3 \mathrm{~km})$ preserves marine and non-marine clastic and carbonate rocks. Thick Carboniferous-Triassic deposits are preferentially preserved in the Macusani structural zone but are very thin or absent in other segments of the Eastern Cordillera. In contrast to Bolivia (McQuarrie, Barnes \& Ehlers, 2008), the Eastern Cordillera of southern Peru preserves pre-Andean unconformities, often angular, among Devonian-Carboniferous, Permo-Triassic and Triassic-Cretaceous strata (Newell, 1949; Mégard et al. 1971; Laubacher \& Mégard, 1985; Sempere et al. 2002). Cenozoic synorogenic deposits ( $>4 \mathrm{~km}$ ) are preserved in the Altiplano and Subandean Zone, with thin restricted accumulations in the Eastern Cordillera.

The axis of a late Palaeozoic - early Mesozoic rift system is proposed along the modern Eastern Cordillera (Sempere et al. 2002). Throughout Peru, rapid lateral changes in facies and thicknesses within the Triassic Mitu Group have been interpreted as non-marine synrift fill deposited on folded Palaeozoic rocks (Reitsma, 2012). Despite widespread preservation of the Mitu Group, only industry reflection seismic datasets from central and northern Peru have identified subsurface pre-Andean normal faults (Hermoza et al. 2005; Eude et al. 2015).

\section{2.b. Geochronologic and thermochronologic records}

Detrital zircon $\mathrm{U}-\mathrm{Pb}$ age spectra help constrain maximum depositional ages, sediment provenance and palaeogeographic reconstructions (Gehrels, 2012). Previous datasets have established the characteristic age populations of Proterozoic, Palaeozoic and Mesozoic rocks exposed throughout the Western and Eastern Cordilleras (Loewy, Connelly \& Dalziel, 2004; Chew et al. 2007, 2008; Mišković et al. 2009; Mišković \& Schaltegger, 2009; Reimann et al. 2010; Bahlburg et al. 2011; Boekhout et al. 2013; Decou et al. 2013; Perez \& Horton, 2014). Here we summarize key U-Pb zircon age populations of potential sediment sources (Western and Eastern Cordilleras, South American craton and Cretaceous-Neogene magmatic arc) to determine preliminary constraints on the provenance and tectonic 


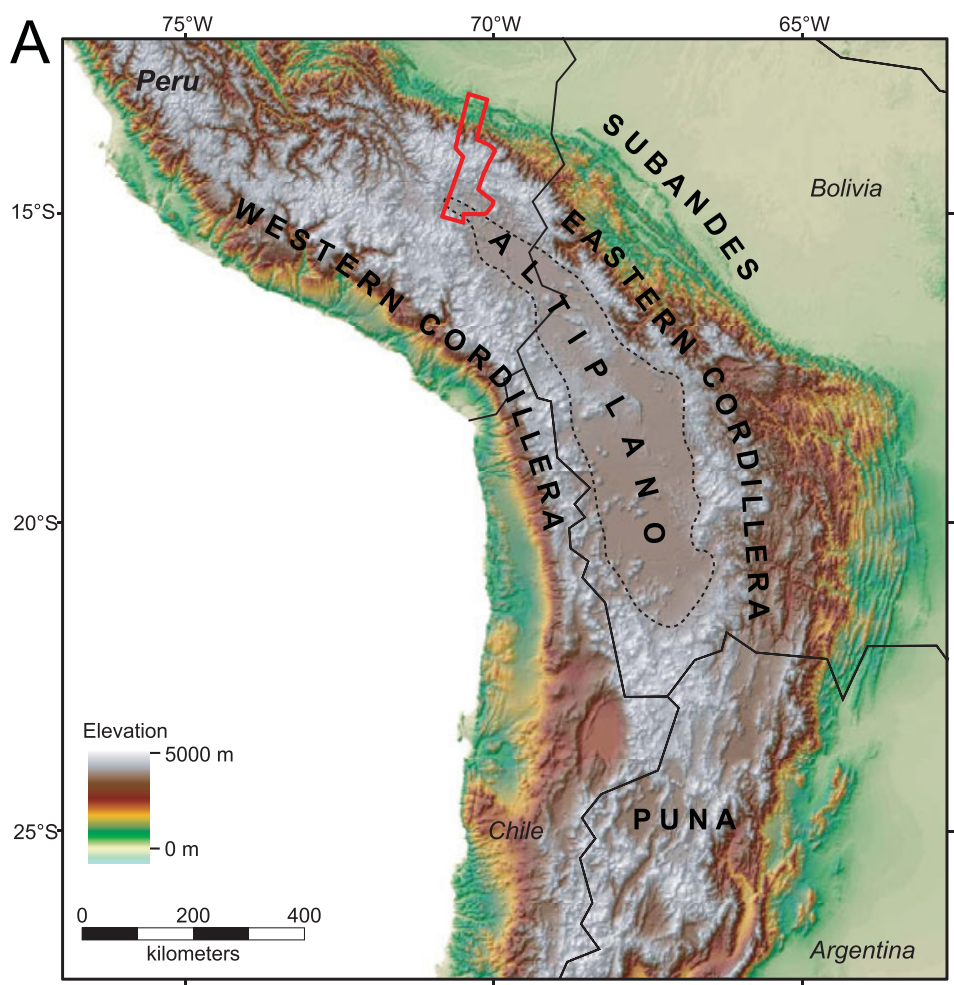

B
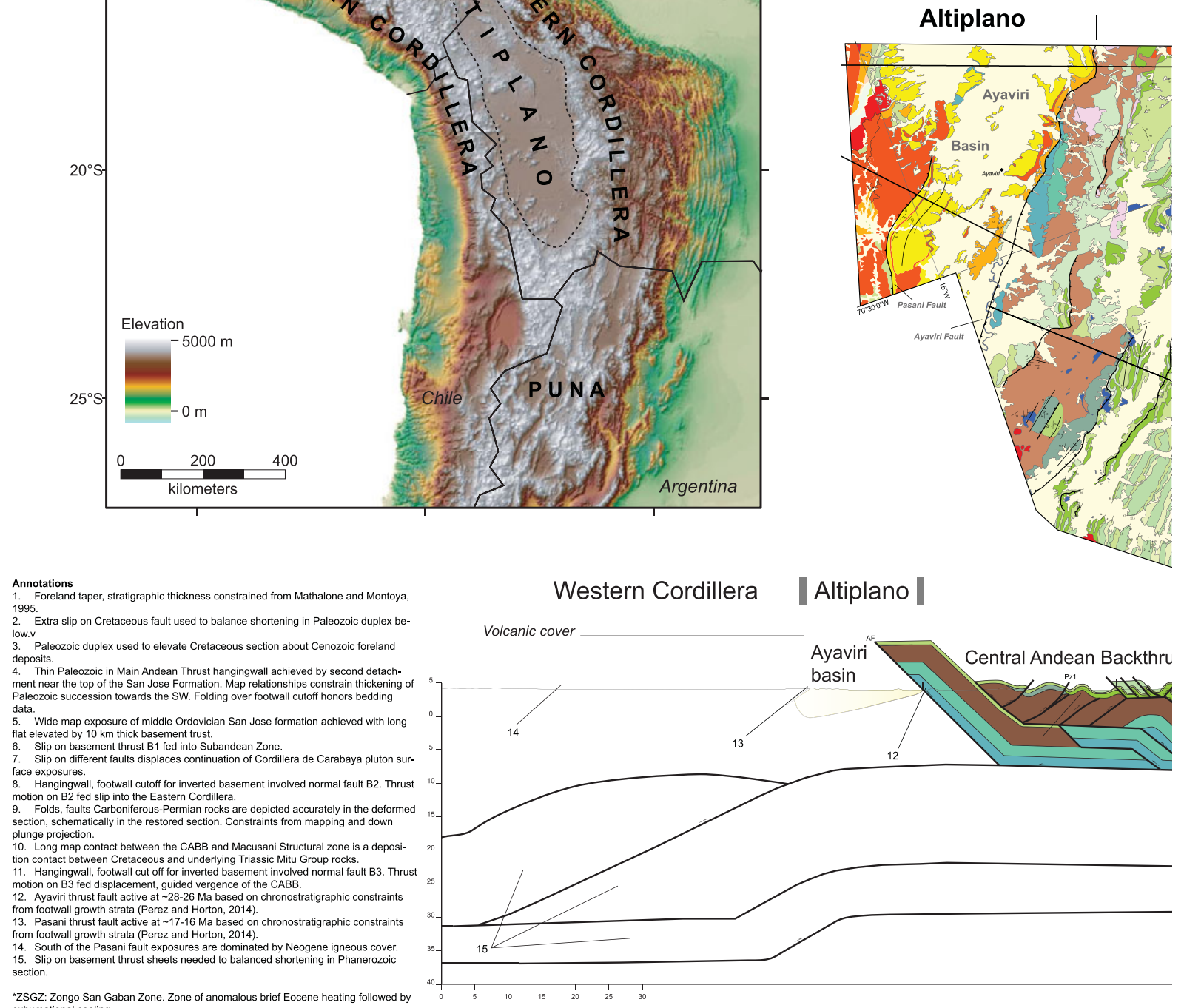

"ZSGZ: Zongo San $G$

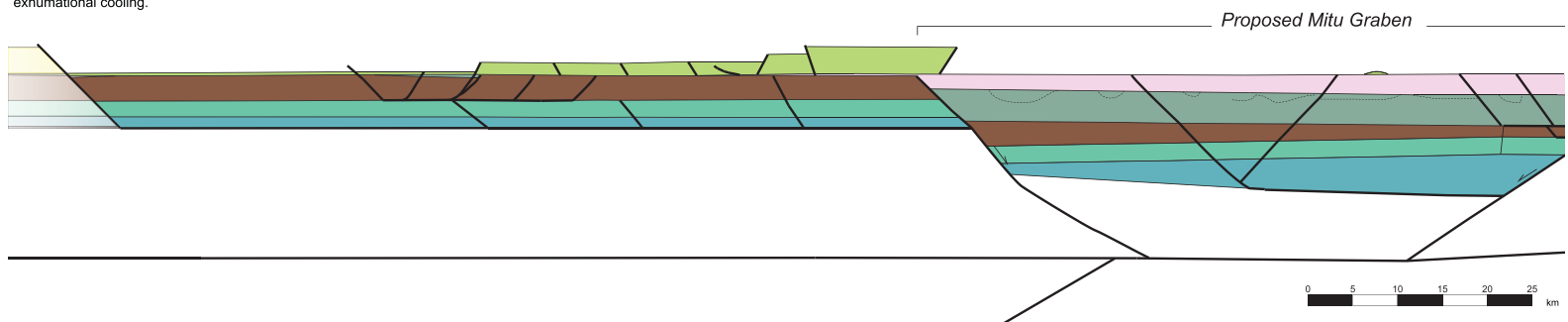

Figure 1. (Colour online) (Large-scale image available in the online Supplementary Material at http://journals. cambridge.org/geo) (a) DEM topography of the central Andes (after Garzione et al. 2014) showing study area (red outline). (b) Compiled 1:100 000 geologic map quadrangles at 1:250 000 scale. Bedding orientation, fault and fold data from own observations Note locations of new and previous thermochronology samples. (c) Line-length balanced cross-section from transects across study area. Cross-section annotations: 1 - Foreland taper, stratigraphic thickness constrained from Mathalone \& Montoya (1995). 2 - Extra slip on Cretaceous fault used to balance shortening in Palaeozoic duplex below. 3 - Palaeozoic duplex used to elevate Cretaceous section about Cenozoic foreland deposits. 4 - Thin Palaeozoic in Main Andean Thrust hanging wall achieved by second detachment near the top of the San Jose Formation. Map relationships constrain thickening of Palaeozoic succession to the SW. Folding over footwall cutoff honours bedding data. 5 - Wide map exposure of Middle Ordovician San Jose Formation achieved with long flat elevated by $10 \mathrm{~km}$ thick basement trust. 6 - Slip on basement thrust B1 fed into Subandean Zone. 7 - Slip on different faults displaces continuation of 


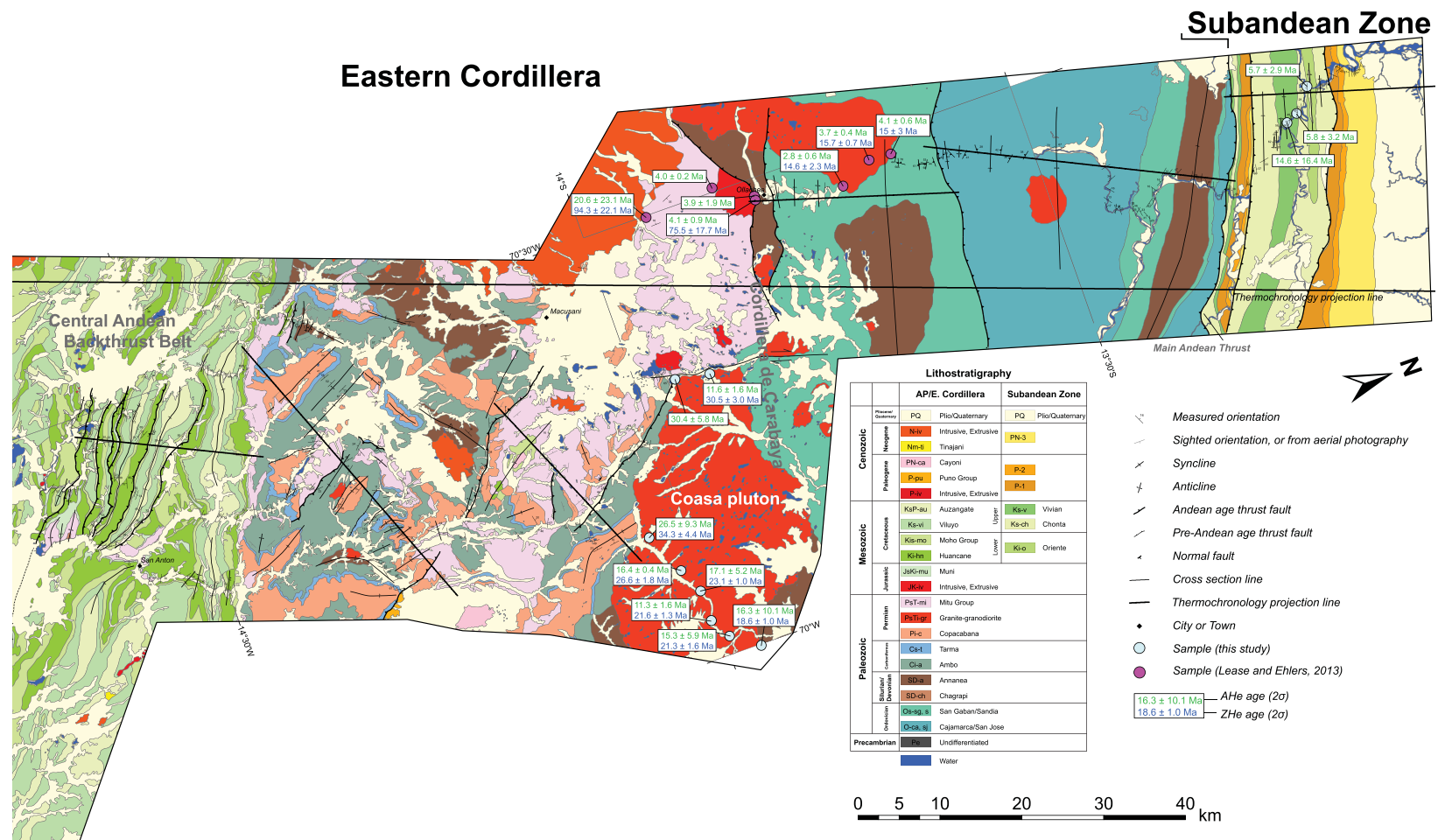

Eastern Cordillera

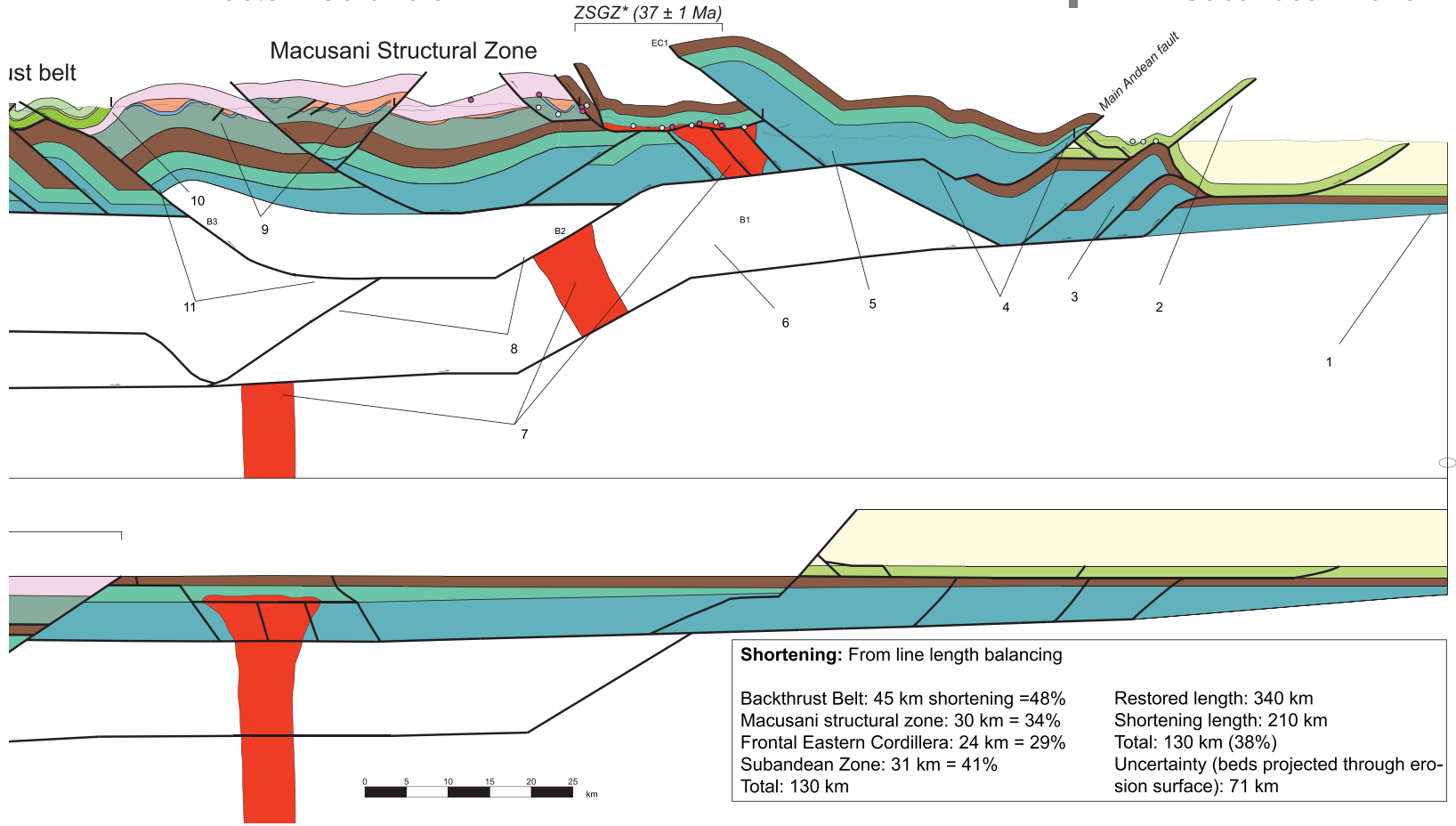

Figure 1. Continued. Cordillera de Carabaya pluton surface exposures. 8 - Hanging wall, footwall cutoff for inverted basement-involved normal fault B2. Thrust motion on B2 fed slip into the Eastern Cordillera. 9 - Folds, faults Carboniferous-Permian rocks are depicted accurately in the deformed section, schematically in the restored section. Constraints from mapping and down-plunge projection. $10-$ Long map contact between the CABB and Macusani structural zone is a deposition contact between Cretaceous and underlying Triassic Mitu Group rocks. 11 - Hanging wall, footwall cut off for inverted basement-involved normal fault B3. Thrust motion on B3 fed displacement, guided vergence of the CABB. 12 - Ayaviri thrust fault active at $\sim 28-26$ Ma based on chronostratigraphic constraints from footwall growth strata (Perez \& Horton, 2014). 13 - Pasani thrust fault active at $\sim 17-16$ Ma based on chronostratigraphic constraints from footwall growth strata (Perez \& Horton, 2014). 14 - South of the Pasani fault exposures are dominated by Neogene igneous cover. 15 - Slip on basement thrust sheets needed to balance shortening in Phanerozoic section. 
framework of Cretaceous through Cenozoic rocks deposited in the Altiplano and Subandean basins.

The Arequipa/Antofalla terrane (basement) is characterized by zircon ages of $476-440 \mathrm{Ma}, \sim 1200$ $940 \mathrm{Ma}$ and $\sim 2020-1790 \mathrm{Ma}$ (Loewy, Connelly \& Dalziel, 2004; Decou et al. 2013). Neoproterozoiclower Palaeozoic rocks of the Eastern Cordillera of Peru are dominated by $\mathrm{U}-\mathrm{Pb}$ zircon ages between $\sim 700-450 \mathrm{Ma}$ and $1300-900 \mathrm{Ma}$, with minor populations of $\sim 2100-1500$ Ma zircons (Chew et al. 2008). Ordovician-Devonian rocks of the Eastern and Western Cordilleras preserve dominantly 800-400 Ma, 1200 $900 \mathrm{Ma}$ and 2200-1600 Ma peaks, with minor occurrences of other populations (Reimann et al. 2010; Bahlburg et al. 2011; Decou et al. 2013; Perez \& Horton, 2014). Plutonic rocks of the Eastern Cordillera show a unique 350-160 Ma signal (Mišković \& Schaltegger, 2009). Mesozoic rocks of the Eastern and Western Cordilleras are characterized by recycled populations observed in Palaeozoic-Proterozoic rocks. The Western Cordillera is distinguished as the main source of Cretaceous-Cenozoic zircons resulting from longlived magmatic-arc activity. Cratonic blocks of eastern South America preserve characteristic age populations: 1200-900 Ma, 1550-1200 Ma, 1800-1550 Ma, 2000$1800 \mathrm{Ma}, 2200-1900 \mathrm{Ma}$ and $>2300 \mathrm{Ma}$ (RestrepoPace et al. 1997; Ramos, 2000; Tassinari et al. 2000; Cordani et al. 2000; Bahlburg, Carlotto \& Cardenas, 2006; Bahlburg et al. 2011).

Although many detrital ages observed in preCretaceous rocks of the Western and Eastern Cordilleras are reworked, three key populations are diagnostic of distinct sediment source areas. Zircon ages of $\sim 350-160 \mathrm{Ma}$ appear limited to Eastern Cordillera sources, Cretaceous-Cenozoic ages are characteristic of the Western Cordillera and $\sim 1400-1300$ Ma ages distinguish Rondonia/San Ignacio sources in Bolivia from other potential South America cratonic block sources. With the establishment of these distinctive populations, provenance signatures in the CretaceousCenozoic record from the Altiplano/CABB and Subandean Zone can potentially be linked with their respective sources.

$\mathrm{K}-\mathrm{Ar}$ and ${ }^{40} \mathrm{Ar}-{ }^{39} \mathrm{Ar}$ ages, and apatite and zircon fission track studies suggest initial exhumation in the Eastern Cordillera of southern Peru and northern Bolivia between $\sim 45$ and $38 \mathrm{Ma}$ (Benjamin, Johnson \& Naeser, 1987; Farrar et al. 1988; Gillis, Horton \& Grove, 2006). In Peru this cooling has been linked to a poorly defined episode of shortening. Apatite and zircon (U-Th)/He results suggest younger Eastern Cordillera cooling attributed to continued thrust deformation and climate change (Lease \& Ehlers, 2013).

\section{Results}

\section{3.a. Geologic mapping}

Mapping and structural transects were conducted and compiled from INGEMMET (1999) 1:100 000 geolo- gic maps. Fault, fold, stratigraphic and/or bedding data were collected at more than 1200 stations along several transects perpendicular to structural grain. The orientations of these transects change across strike as fault and fold orientations vary. Breaks in section occur on structures that can be mapped along strike. Below we discuss key elements of morphotectonic domains within the study area.

\section{3.a.1. Foreland}

Reflection seismic and borehole datasets for the Madre de Dios foreland basin show $<2 \mathrm{~km}$ Cretaceous and $>4 \mathrm{~km}$ Cenozoic sequences unconformably deposited on a lower Palaeozoic succession above a $\sim 2^{\circ}$ SW-dipping basement-cover interface (Mathalone \& Montoya, 1995). Surface exposures are dominated by Neogene-Quaternary clastic deposits. Modern fluvial traces are often parallel to exposed frontal Subandean structures, suggesting that long-wavelength, lowamplitude folds accommodating deformation guide fluvial channels.

\section{3.a.2. Subandean Zone}

The Subandean Zone is characterized by a $\sim 12-13 \mathrm{~km}$ wide zone of Cretaceous marine siliciclastic rocks deformed mostly by NW-trending, upright, non-plunging, $\sim 5-6 \mathrm{~km}$ spaced folds with $\sim 20-60^{\circ}$ bedding dips. Two major thrust faults juxtapose Cretaceous marine siliciclastic rocks on Palaeogene fluvial siltstones and sandstones (INGEOMIN, 1975; Mathalone \& Montoya, 1995; Kley, Monaldi \& Salfity, 1999). Local, outcrop-scale intraformational duplexes and tight folds are rare (Fig. 2a, b). These features are considered minor relative to thrust faults that offset the Cretaceous and Cenozoic strata, but suggest that total shortening may be higher than quantified by geologic mapping or cross-section construction. The deepest structural level observed is the Lower Cretaceous Oriente Group exposed in anticlines and thrust fault hanging walls (Mathalone \& Montoya, 1995).

\section{3.a.3. Eastern Cordillera}

The frontal Eastern Cordillera exhibits an abrupt change in structural style and $>10 \mathrm{~km}$ increase in exposed stratigraphic levels across the Main Andean Fault compared to the Subandean Zone. Map patterns define major folds of $\sim 30 \mathrm{~km}$ wavelength. The deepest structural level exposed is the Middle Ordovician San Jose Formation, suggesting a regional décollement above the basement contact. At the outcrop scale, rocks exhibit a variety of tight folds over short distances, kilometre-wide panels of similar dips, and bedding orientations that are both parallel to Andean NW-SE trends $\left(\sim 290-300^{\circ}\right.$ or $\left.110-120^{\circ}\right)$ or oblique $\left(\sim 350^{\circ}\right)$, similar to patterns observed in the Bolivian Eastern Cordillera (Eichelberger et al. 2013). 


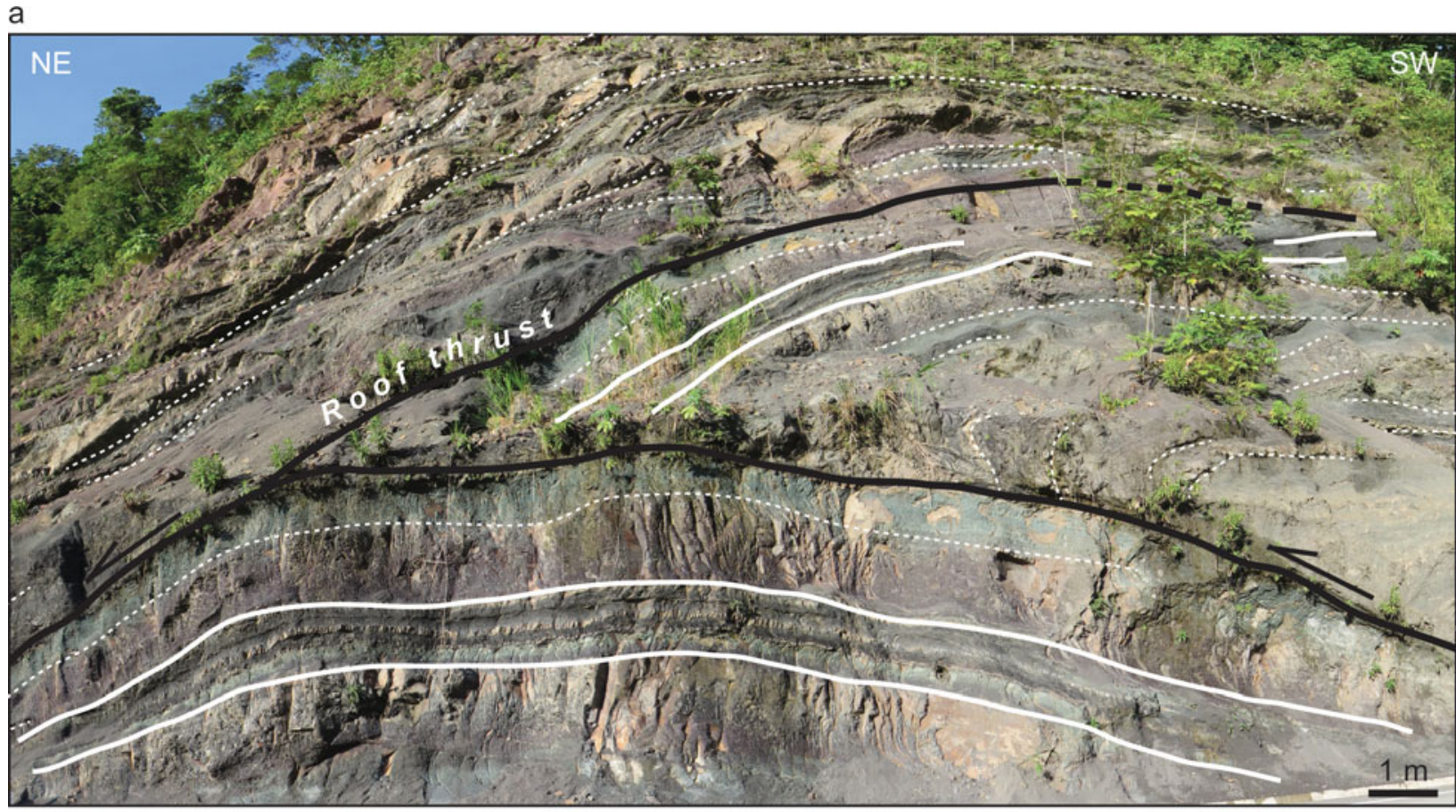

b

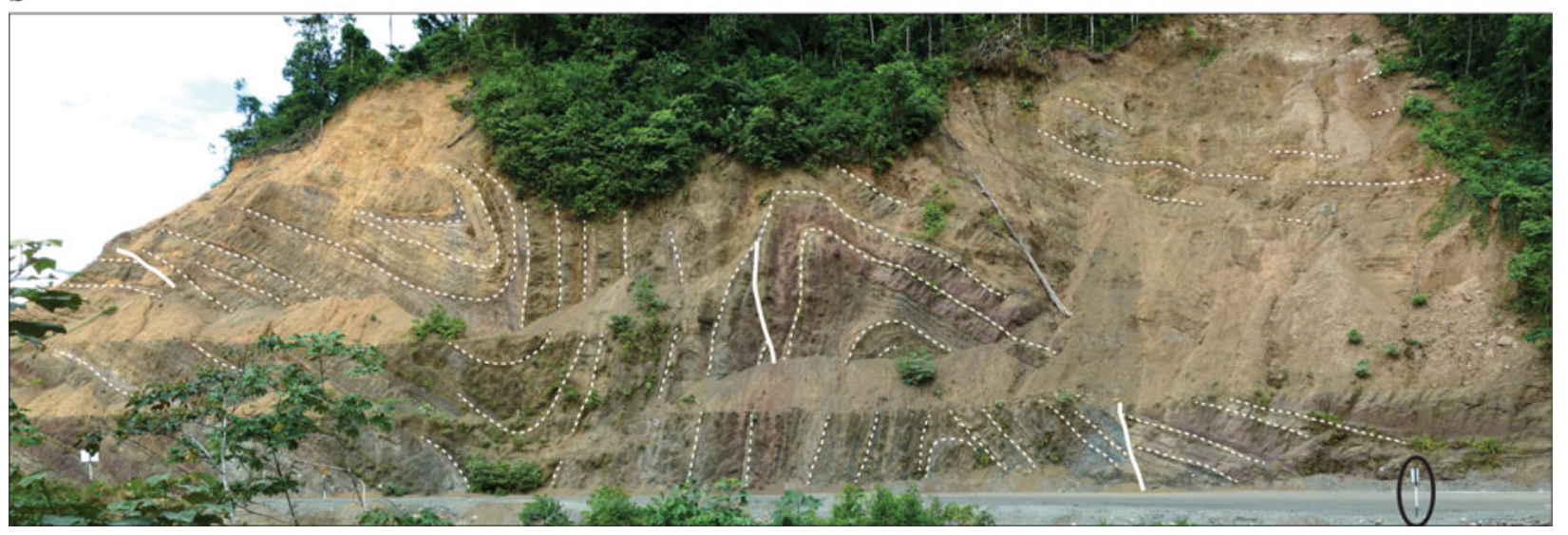

Figure 2. (Colour online) Examples of minor tens of metres-scale folding below resolution of mapping and cross-section. (a) Outcropscale duplex of Cretaceous rocks from the Subandean Zone. (b) Road-cut of folded Cretaceous rocks from the Subandean Zone. Note highway sign circled for scale is $c .2 \mathrm{~m}$ high.

In detail, we observe three zones with discrete stratigraphic levels in the Eastern Cordillera. (1) The $\sim 35 \mathrm{~km}$ wide NE zone is characterized by a broad syncline/anticline pair that deforms Middle Ordovician to Silurian-Devonian meta-sedimentary rocks and Triassic plutons. Lateral variations in Ordovician unit thickness suggest original stratigraphic geometries tapered towards the craton. (2) The axial zone ( $\sim 21 \mathrm{~km}$ wide) is separated from the NE zone by a NE-dipping, SWverging thrust fault that places the Middle Ordovician San Jose Formation on the Upper Ordovician Sandia Formation. The axial zone is characterized by a broad map syncline, with smaller scale internal folds concentrated towards the SW boundary, and a consistent structural level throughout. These Ordovician rocks are metamorphosed near a large Triassic pluton. The axial zone is thrust over the (3) SW zone of Silurian-
Devonian rocks $(\sim 10 \mathrm{~km}$ wide $)$ that are the structurally highest level within the frontal Eastern Cordillera. The SW zone is thrust over the Cordillera de Carabaya/Macusani structural zone by a NE-dipping reverse fault.

\section{3.a.4. Cordillera de Carabaya/Macusani structural zone}

The Cordillera de Carabaya is defined by PermoTriassic plutons that intrude Ordovician-Carboniferous strata (McBride, Robertson \& Clark, 1983; Clark et al. 1990; Kontak et al. 1990; Sandeman, Clark \& Farrar, 1995; Mišković et al. 2009) and smaller, rare Jurassic plutons that intrude Triassic Mitu Group deposits. The plutons are aligned with the NW-SE Andean structural grain. The NE margin of the Macusani structural zone is defined by the SW-directed thrust contact between the 

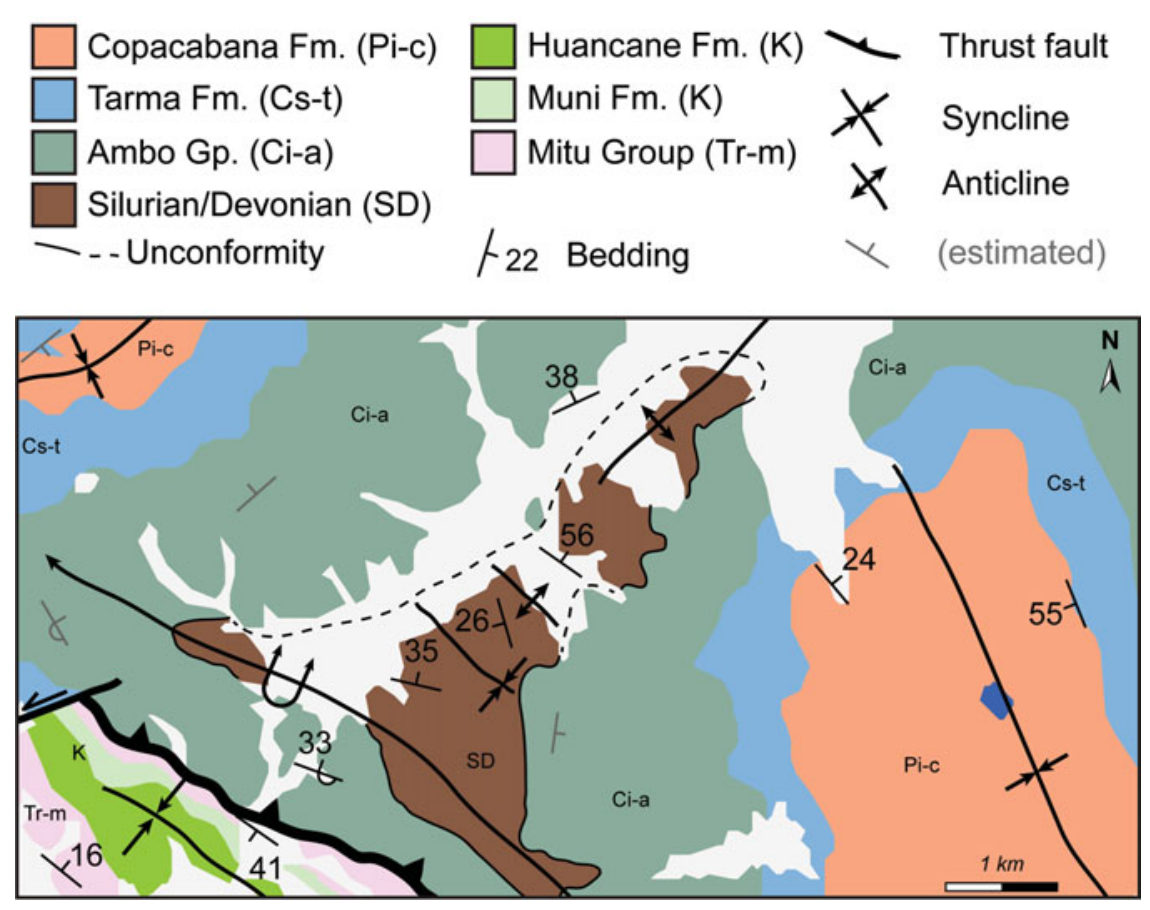

Figure 3. (Colour online) Map from Macusani structural zone (see Fig. $1 \mathrm{~b}$ for location) highlighting multiple pre-Andean deformation phases preserved in the area. Note folds in Silurian-Devonian beneath angular unconformity with overlying Carboniferous; multiple fold orientations in Carboniferous-Permian rocks; Silurian-Permian succession thrust over Triassic Mitu Group and Cretaceous rocks.

Cordillera de Carabaya plutons and the Eastern Cordillera. The SW boundary is the depositional contact with the CABB.

The Macusani structural zone maintains a consistent structural elevation $\sim 50 \mathrm{~km}$ across strike. Our mapping confirms three main phases of pre-Andean deformation in the region, which have been proposed previously (Mégard et al. 1971; Laubacher, 1978; Mégard, 1978; Dalmayrac, Laubacher \& Marocco, 1980; Laubacher \& Mégard, 1985; Jimenez, Lopez-Velasquez \& Santivañez, 2009). The first phase (known as Eohercynian deformation) occurred during Late Devonian - Early Carboniferous time and folds Silurian-Devonian rocks about NW-trending, shallowing plunging synclines and anticlines (Dalmayrac, Laubacher \& Marocco, 1980; Laubacher \& Mégard, 1985). These folds are truncated by an erosional unconformity and covered by a $\sim 4 \mathrm{~km}$ thick succession of Carboniferous-Permian shales, quartzites and carbonates (Fig. 3). These upper Palaeozoic units dominate exposures in the Macusani structural zone beneath Mitu Group deposits. The Carboniferous-Permian rocks preserve faults and folds attributed to a second, late Permian, deformation phase ('Late Hercynian'). Faults and folds that deform upper Palaeozoic strata often have short map traces $(\sim 10$ and $\sim 6-7 \mathrm{~km})$ and a $\sim 6-$ $7 \mathrm{~km}$ fold wavelength with NW and NE sigmoidal orientations that are conspicuously oblique or nearly perpendicular to regional Andean trends. These have been interpreted as originally NW-trending en échelon folds that formed in a left-lateral shear zone and were refolded, potentially by continued deformation or changing stress orientations (Laubacher, 1978). Al- ternatively, similar sigmoidal structures have been interpreted as fold interference patterns related to basement-involved thrusts (Carrera et al. 2006). Noncoaxially deformed upper Palaeozoic strata $(\sim 4 \mathrm{~km}$ thick) occur only in the Macusani structural zone and are absent from the CABB, Eastern Cordillera and Subandean Zone. A second erosional unconformity separates folded Carboniferous-Permian rocks from the overlying Triassic Mitu Group (Fig. 4). Despite proposed deposition in a Triassic rift environment (Newell, 1949; Sempere et al. 2002; Reitsma, 2012), only one associated normal fault has been identified at outcrop scale (Fig. 4). The Mitu Group is cut by NNW-trending thrust faults that fold Cretaceous strata and are parallel to late Permian structures likely reactivated during Andean deformation.

\section{3.a.5. Central Andean Backthrust Belt}

The CABB is a $\sim 50 \mathrm{~km}$ wide NW-trending fold-thrust system dominated by Cretaceous rocks. The NE margin is defined by a depositional contact between Upper Jurassic to Lower Cretaceous Muni Formation rocks, and Triassic Mitu Group to upper Palaeozoic rocks of the Macusani structural zone. Faults and folds in the CABB are developed mostly in Cretaceous strata and verge to the SW. Faults are spaced $\sim 1-3 \mathrm{~km}$ apart and field relationships suggest an imbricate fan, as no evidence of a roof thrust is preserved. Isolated erosional windows in anticline cores expose Lower Cretaceous Muni Formation rocks capping thin $(<300 \mathrm{~m})$ accumulations of Triassic Mitu Group rocks on top of Silurian-Devonian strata. In the CABB, the Mitu Group preserves 


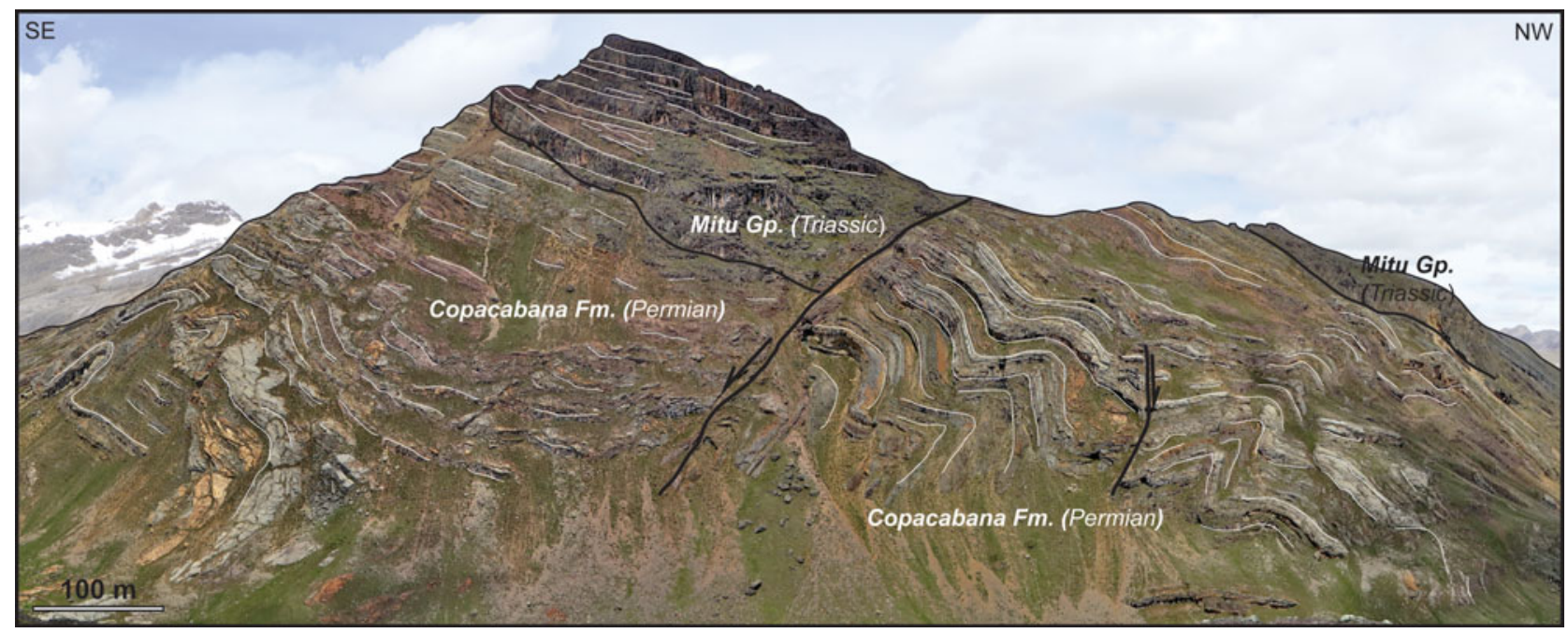

Figure 4. (Colour online) Outcrop example of Triassic normal fault accommodating synrift accumulation of Mitu Group rocks. Note folded Permian carbonates unconformable below Mitu Group rocks, attributed to late Permian shortening. See location in Figure $1 \mathrm{~b}$.

evidence for pre-Cretaceous folding and spaced penetrative fabric formation (Fig. 5). The nature and distribution of such deformation remains unclear.

Thrust fault hanging walls juxtapose Lower Cretaceous Muni Formation or Huancane Formation rocks on younger Cretaceous strata. Most hanging wall cutoffs are eroded. Fold limbs may be moderate $\left(20-30^{\circ}\right)$ to steeply dipping $\left(70-80^{\circ}\right)$. Map and field relationships suggest rounded, concentric folds rather than fault-bend folds. Tight, disharmonic folds are observed in some exposures of Lower Cretaceous Ayavacas Formation carbonates (Fig. 6). Other outcrop and map-scale examples of complex fold patterns have been interpreted as features of slump and mass-wasting deposits (Callot, Odonne \& Sempere, 2008; Callot et al. 2008).

The SW zone of the CABB exposes deeper structural levels in lower Palaeozoic rocks across a $\sim 15 \mathrm{~km}$ wide region of E- and W-verging faults. An E-directed thrust along the NE margin of this narrow zone thrusts Carboniferous Ambo Formation quartzites on Cretaceous rocks. Within this zone, localized exposures of Carboniferous and Silurian-Devonian rocks are thrust over thin accumulations of Lower Cretaceous rocks of unknown original thickness. The SW CABB boundary is the Ayaviri fault (Sempere et al. 1990; Carlotto, 2013) with Middle Ordovician Calapuja Formation rocks in the hanging wall. In this $\sim 15 \mathrm{~km}$ wide zone, Cretaceous rocks are deposited over Triassic or SilurianDevonian rocks, resulting in a locally variable subcrop relationship.

\section{3.a.6. Altiplano}

Up to $3 \mathrm{~km}$ of fluvial and alluvial fan deposits of the Oligocene Puno Group and Miocene Tinajani Formation rocks fill the Ayaviri basin (Rodriguez, Flores \& Marocco, 1999; Ibarra et al. 2004; Rousse et al. 2005; Carlotto, 2013; Perez \& Horton, 2014). The basin is bounded to the NE and SW by the Ayaviri backthrust and the Pasani thrust, respectively, and folded into a NW-trending asymmetric syncline, with NE limb dips generally $10-15^{\circ} \mathrm{SW}$ and SW limb dips $\sim 50-70^{\circ}$ NE. Footwall growth strata constrain motion along the Ayaviri and Tinajani faults to Oligocene and middle Miocene time, respectively, and suggest hybrid trishear and fault-propagation fold kinematics (Perez \& Horton, 2014).

\section{3.b. Cross-section}

Balanced cross-sections provide potential subsurface structural geometries, estimates of regional strain and kinematic insights on crustal structure development (Bally, Gordy \& Stewart, 1966; Dahlstrom, 1969; Boyer \& Elliott, 1982; Elliott, 1983; Woodward, Boyer \& Suppe, 1989). The technique has been applied throughout the Andes and other fold-thrust belts to estimate bulk shortening and crustal thickening, and to evaluate fault kinematics and rift inversion (Beach, 1981; Price, 1981; Boyer \& Elliot, 1982; Roeder, 1988; Baby et al. 1992; Kley, 1996; Baby et al. 1997; Kley \& Monaldi, 1998; McQuarrie, 2002a; Teixell et al. 2003; Elger, Oncken \& Glodny, 2005; Mora et al. 2006; McQuarrie, Barnes \& Ehlers, 2008; Gotberg, McQuarrie \& Carlotto, 2010; Giambiagi et al. 2011; Eichelberger et al. 2013; Eude et al. 2015). These examples rely mostly on sinuous-bed and line-length balancing techniques, which assume no out-of-plane motion, no metamorphism and volume conservation throughout deformation.

Some limitations of line-length balancing include poorly defined uncertainty estimates, limited constraints regarding how subsurface space is filled and the length of eroded hanging wall cutoffs projected above the surface. In addition, Judge \& Allmendinger (2011) showed that the original stratigraphic thickness is the largest source of error. They proposed area balancing as an alternative technique because it provides 


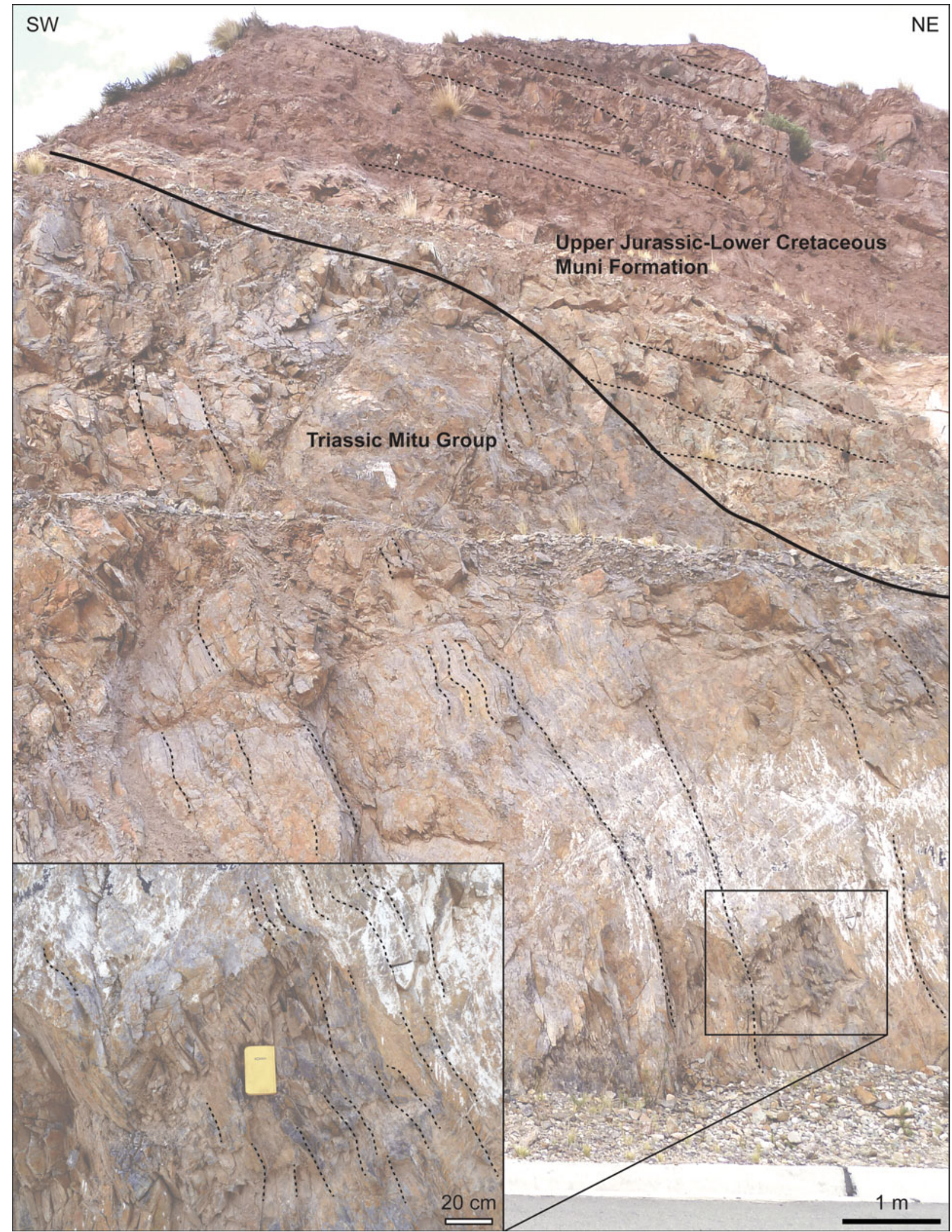

Figure 5. (Colour online) Road-cut example of penetrative foliation development and minor folds in Triassic Mitu Group rocks beneath angular unconformity overlain by Cretaceous rocks. Note yellow field notebook for scale is $19 \mathrm{~cm}$ long.

improved ability to analyse uncertainties. However, by only determining an area-balanced solution, the proposed errors cannot be assessed to ensure viability (Eichelberger et al. 2013). Our cross-section does not restore to a stratigraphic wedge with a uniform taper that is the default for the area-balancing technique. Instead, the restoration supports a graben geometry that reflects rapid changes in stratigraphic thickness associated with Triassic rifting and faults offsetting basement. Therefore, we rely on our line-length balanced section 


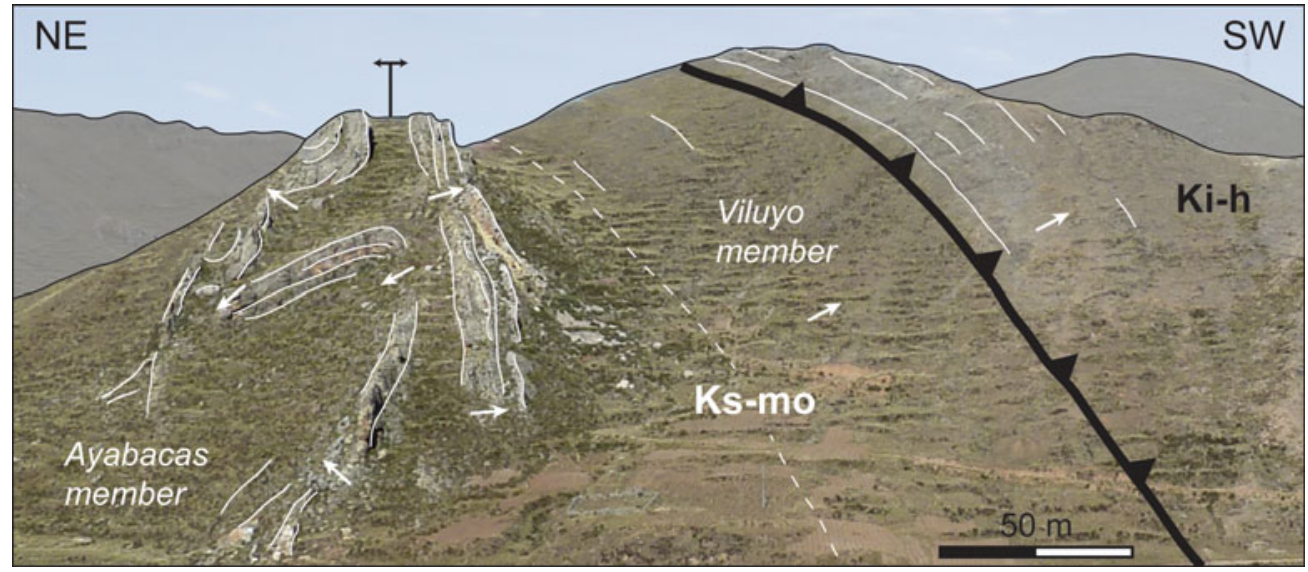

Figure 6. (Colour online) Outcrop example of non-harmonic folds typical of Cretaceous Ayavacas Formation exposures in the Central Andean Backthrust Belt. White arrows show direction of stratigraphic younging. These rocks are in the footwall of a thrust, and local exposures of gypsum suggest folding is tectonically driven. Ks-Mo - Upper Cretaceous Moho Group; Ki-h - Lower Cretaceous Huancane Formation.

to provide shortening estimates rather than the areabalance technique outlined by Judge \& Allmendinger (2011).

The cross-section was constructed from a 1:250 000 geologic map compiled from 1:100 000 maps and honours map patterns, faults, folds, changes in structural level and bedding orientation. We have identified five changes in structural elevation that are variably achieved by duplexes in Palaeozoic stratigraphy, basement thrust ramps and inverted Triassic normal faults. Because variable exposure and access do not permit a single cross-section line, we chose to create multiple section lines to accurately capture the maximum information. During our mapping, we did not observe any strike-slip faults, supporting our assumption of minimal out-of-plane motion. Transport directions are perpendicular to the dominant structural grain, which shifts gradually from $\sim 310^{\circ}$ in the Altiplano to $\sim 290^{\circ}$ in the Subandean Zone. Strike directions in the Macusani structural zone of $\sim 340^{\circ}$ and $040^{\circ}$ force us to use section lines of variable orientations.

\section{3.b.1. Subandean Zone}

The narrow structural spacing and lack of preCretaceous Subandean rocks suggest a detachment at the base of the Cretaceous. The structural elevation of exposed Subandean Cretaceous rocks above the adjacent $4-5 \mathrm{~km}$ thick Cenozoic foreland basin fill is best achieved by duplexing the $\sim 4 \mathrm{~km}$ thick DevonianOrdovician succession. No Palaeozoic rocks are exposed in the Subandean Zone of southern Peru. Multiple major structures in the Eastern Cordillera have hanging wall flats in the Ordovician, suggesting the horizon is an important regional detachment. We use this detachment to create the three horses in the hinterlanddipping duplex, and structurally elevate the Cretaceous. The space occupied by this duplex could have also been filled with a basement thrust sheet, but this configuration would not have allowed sufficient space to shorten the Palaeozoic the same amount as the Cretaceous, or support structures imaged on adjacent reflection seismic lines (W. F. Gil Rodriguez, unpub. Ph.D. thesis, Univ. Paul Sabatier, 2001). We proposed that the frontal thrust has $\sim 13 \mathrm{~km}$ of slip. This slip is necessary to balance shortening in the Palaeozoic duplex at depth. Subandean folds are formed by ramp-flat deformation along the Cretaceous detachment, or by the subsurface duplex. Shortening of the Cretaceous rocks exposed at the surface and matching shortening of the Palaeozoic duplex at depth is accommodated by slip on the frontal basement thrust sheet (B1, Fig. 1c).

\section{3.b.2. Eastern Cordillera}

The Eastern Cordillera represents a second major increase in structural relief and is characterized by a $>50 \mathrm{~km}$ wide structural high exposing OrdovicianDevonian strata intruded by Triassic plutons. The SWdipping Main Andean Thrust juxtaposes a syncline developed in Ordovician-Devonian strata against Cretaceous rocks. Map relationships show that the strata exposed on the NE syncline limb is thinner than the SW limb. We propose that the SW increase in Palaeozoic map thickness is structural and suggest a second flat near the top of the Middle Ordovician San Jose Formation. This thinner section of Ordovician rocks exposed in the hanging wall restores to a footwall cutoff and flat proposed on the westernmost horse in the Subandean duplex. Structural elevation of Ordovician rocks above Cretaceous rocks is achieved by motion of a $10 \mathrm{~km}$ thick basement thrust sheet over a basement ramp and an increase of the basement dip to $4^{\circ}$. Slip on this frontal basement thrust is accommodated by shortening of the duplex and Cretaceous thrust faults in the Subandean Zone and slip on the Main Andean Fault. The frontal section of the Eastern Cordillera is comprised of a single, $\sim 30 \mathrm{~km}$ wide thrust sheet elevated above the basement thrust. Some deformation of this upper thrust sheet is achieved by folding over the 
proposed footwall fault geometry, and folding of the westernmost Subandean horse into a syncline, with the western limb tilted by the basement thrust sheet.

Within the Eastern Cordillera structural high, three structural levels become successively shallower towards the hinterland corresponding with increasing surface elevation. We modelled this pattern as a décollement horizon that climbs up from the base of the middle Ordovician, to the base of the upper Ordovician, and to the base of the Silurian-Devonian. A small duplex with a $\mathrm{W}$-verging sense of displacement elevates the upper Ordovician, and repeated Silurian-Devonian rocks achieve the third, structurally shallowest zone of the Eastern Cordillera. Although this zone of the crosssection now appears as a large passive roof duplex over the underlying basement thrust sheet B1, we note that slip on B1 is fed to the Main Andean Thrust and the Subandean Zone, not the Eastern Cordillera. Rather, we suggest that slip into this zone of backthrusts in the Eastern Cordillera is restored to a basement thrust sheet B2 that was thrust onto the frontal basement sheet B1. We suggest map exposures of Triassic plutons have been translated to the NE owing to motion of basement thrust B1 (Fig. 1b, c). After restoration of the cross-section, we projected schematic pluton roots at depth presently situated beneath the Macusani structural zone.

\section{3.b.3. Macusani structural zone}

The Cordillera de Carabaya plutons were carried in the hanging wall of SW-verging thrust faults over Triassic and upper Palaeozoic rocks along the NE Macusani structural zone margin. The Macusani structural zone exhibits shallower structural elevation than the Eastern Cordillera. We propose that the Eastern Cordillera exposure levels are deeper because they have travelled over the frontal basement ramp, whereas Macusani structural zone exposure levels are shallower because they have not been translated over the frontal basement ramp.

We honour some pre-Andean deformational geometries by showing faults and folds in CarboniferousPermian rocks preserved beneath Triassic Mitu Group deposits in the deformed section, but do not attempt to restore pre-Triassic shortening in the restored section. We do not attempt to model deformational geometries associated with pre-Carboniferous deformation because of limited Ordovician-Devonian exposures. Instead the Ordovician-Devonian rocks are depicted as continuous parallel units, although they preserve pre-Andean deformation fabrics and were probably the main décollement levels for late Permian deformation.

Field and map data demonstrate deformation of Cretaceous and Triassic Mitu Group rocks and reveal key Andean thrust fault locations that are often aligned with late Permian compressional structures, but have longer map traces, suggesting they have reactivated and further propagated existing structural features. Thrust spacing is $\sim 15-16 \mathrm{~km}$. Slip along individual faults is generally $<5 \mathrm{~km}$. The broad folds, wide thrust fault spacing and thick deformed sedimentary cover suggests basement-involved thick-skinned shortening within the Macusani structural zone.

\section{3.b.4. Central Andean Backthrust Belt}

Field and map data demonstrating close fault spacing (1-3 km), Lower Cretaceous rocks consistently in thrust fault hanging walls and tight folds suggest the décollement probably occupies the Lower Cretaceous Muni Formation, which is a fine-grained marine siltstone. The thin-skinned structural style of the CABB contrasts with the thick-skinned style of the Macusani structural zone. A secondary detachment at the base of the Ayavacas Formation (lower Moho Group) may locally utilize evaporite deposits and create tight, disharmonic folds in the footwalls of some thrust faults (Fig. 6). The Cretaceous section thins from $\sim 2 \mathrm{~km}$ to $<1 \mathrm{~km}$ to the SW. The NE margin of the CABB is more highly deformed with tighter folds and multiple thrust faults, whereas the SW margin is deformed by open folds and fewer thrust faults. This suggests that deformation propagated from the NE to SW, creating an in-sequence imbricate fold-thrust belt that transferred displacement from the Eastern Cordillera to the Altiplano.

Cretaceous rocks in the $\mathrm{CABB}$ are deposited with an angular unconformity on thin $(<300 \mathrm{~m})$ Triassic Mitu Group deposits, which are disconformable with the underlying Silurian-Devonian strata. In general, we suggest that the CABB was mostly a highstanding, eroding block during Triassic rifting. Nearly all Carboniferous-Permian rocks that may have been present were eroded, and only thin accumulations of synrift Mitu Group deposits were preserved in the hanging walls of minor normal faults.

Shortening of the Cretaceous rocks is achieved by duplexing and equivalent shortening of the Ordovician to Devonian strata. Here, we model two detachments to accommodate Palaeozoic shortening. At the NE CABB margin, beneath the more tightly deformed Cretaceous rocks, one detachment at the base of the Ordovician creates a SW-verging duplex. The décollement ramps up to the base of the Silurian-Devonian beneath the zone of the more broadly folded Cretaceous rocks. In one horse of this Silurian-Devonian duplex, a thin carapace of Carboniferous Ambo group rocks is preserved beneath thin Cretaceous deposits. The frontal thrust of the CABB is the Ayaviri fault, which utilizes the main décollement at the base of the Ordovician.

\section{3.b.5. Shortening magnitudes}

Our line-length balanced cross-section has a deformed length of $210 \mathrm{~km}$ measured between the Ayaviri fault and the foreland pin line and a restored length of $340 \mathrm{~km}$, yielding $130 \mathrm{~km}$ or $38 \%$ of shortening. This includes $31 \mathrm{~km}$ in the narrow Subandean Zone, $24 \mathrm{~km}$ 
in the frontal Eastern Cordillera, $30 \mathrm{~km}$ in the Macusani structural zone and $45 \mathrm{~km}$ in the CABB.

The shortening estimates are similar to the preferred estimate of $123 \mathrm{~km}(40 \%)$ reported by Gotberg, McQuarrie \& Carlotto (2010) for a section 100$150 \mathrm{~km}$ along strike to the NW. In northern Bolivia, A. J. Rak (unpub. M.S. thesis, Univ. Pittsburgh, 2015) and McQuarrie, Barnes \& Ehlers (2008) documented $242 \mathrm{~km} \mathrm{(43 \% )} \mathrm{and} 276 \mathrm{~km}(40 \%)$ of shortening, respectively, further highlighting the along-strike gradient in total shortening from Bolivia to Peru (Gotberg, McQuarrie \& Carlotto, 2010).

\section{3.c. Detrital zircon U-Pb geochronology}

$\mathrm{U}-\mathrm{Pb}$ geochronology of foreland basin fill provides insights into sediment routing pathways, depositional ages and the tectonic evolution of orogens (Dickinson \& Gehrels, 2003; Horton et al. 2010; Lawton \& Bradford, 2011; Gehrels, 2012). We investigate the provenance of the Cretaceous-Cenozoic stratigraphic sections preserved in the $\mathrm{CABB} /$ Altiplano and Subandean Zone. Today, the two regions are separated by $>100 \mathrm{~km}$ across the Eastern Cordillera, where proposed Cenozoic and Cretaceous deposits are restricted to thin, localized exposures. By defining the Cretaceous-Cenozoic provenance signatures from both regions, we evaluate whether the depocentres represent two long-lived, separate basins or a once-continuous basin that was partitioned during Eastern Cordillera uplift. For detailed methods, see online Supplementary Material available at http://cambridge.journals.org/geo.

\section{3.c.1. Overview}

We present detrital zircon $\mathrm{U}-\mathrm{Pb}$ results from 11 Altiplano/CABB samples and 9 Subandean Zone samples $(\mathrm{n}=1997$ grains) (Fig. 7). We note distinct differences in zircon provenance between the two regions since at least Early Cretaceous time. The Cretaceous to Cenozoic record in the Altiplano/CABB is characterized by detrital zircon age populations that reflect distinctive Eastern and Western Cordillera sources. Detrital zircon ages from Altiplano/CABB Cretaceous rocks are characteristic of Eastern Cordillera sources, whereas Altiplano/CABB Cenozoic rocks reflect principally Western Cordillera contributions. In contrast, Subandean Zone Cretaceous to Cenozoic rocks record long-lived cratonic sediment sources rather than the Andean Cordilleras.

\section{3.c.2. Altiplano and $C A B B$}

Five Cretaceous samples (Muni, Huancane, Vilquechico, Auzangate and Viluyo formations) were collected from marine sandstones exposed in the CABB $(n=$ 504 grains). All five samples exhibit detrital zircon age populations that are found in Palaeozoic rocks of the Eastern Cordillera ( 400-800 Ma, $\sim 900-1200 \mathrm{Ma},>$ $1300 \mathrm{Ma})$. However, we consider the presence of Gond- wanide zircons ( 350-160 Ma) (Mišković \& Schaltegger, 2009), which are characteristic of plutons exposed in the Eastern Cordillera, as diagnostic of a strong Eastern Cordillera provenance during Cretaceous deposition. Few $(\mathrm{n}<10)$ Cretaceous age zircons have been analysed from the five samples. Six previously reported Cenozoic samples (Puno/San Jeronimo Groups and Tinajani formations) from the northern Altiplano reveal a transition to a dominantly Western Cordillera sediment source (Perez \& Horton, 2014; Horton et al. 2015). Cenozoic detrital zircon ages dominate the six samples $(\mathrm{n}>100)$, with a lesser contribution from Cretaceous detrital zircon ages $(\mathrm{n}=$ 30). The high proportion of Cretaceous and Cenozoic grains in the Cenozoic rocks suggests E-directed sediment transport sourced from the Western Cordillera. Some Cenozoic samples from the Altiplano also contain zircon populations that are characteristic of an Eastern Cordillera provenance, suggesting zircon recycling or continued sediment source areas in the Eastern Cordillera.

\section{3.c.3 Subandean Zone}

Three Cretaceous samples (Vivian and Oriente formations) from the Subandean Zone ( $\mathrm{n}=317$ grains) lack Cretaceous and Gondwanide zircons characteristic of the Western and Eastern Cordilleras, respectively. The 400-800 Ma population is a minor component of the Cretaceous Subandean Zone population. Unlike Cretaceous rocks from the $\mathrm{CABB}$, most detrital zircon ages from Cretaceous rocks of the Subandean Zone compose a broad distribution of 1600-900 Ma zircons, with a key peak between 1400-1300 Ma. This zircon age population is very minor throughout Western and Eastern Cordillera rocks, but is characteristic of the Rondonia/San Ignacio cratonic block of Bolivia. We suggest that Cretaceous rocks from the Subandean Zone record W-directed sediment transport sourced primarily from cratonic blocks because they lack diagnostic Andean zircon ages.

Six Cenozoic samples (Pozo and Chambira formations) from the Subandean Zone and foreland basin $(n=617)$ record persistent cratonic source areas and the appearance of Andean detrital zircon ages. A broad population of 1600-900 Ma zircons is present, characterized by a dominant peak between 1400-1300 Ma. The abundance of 700-500 Ma zircons is higher than in Cretaceous Subandean samples. The appearance of Gondwanide zircons and five Cretaceous zircons suggests that the Subandean Zone received a minor contribution from Andean sources during Cenozoic deposition. No Cenozoic detrital zircons have been analysed from Cenozoic samples in the Subandean Zone or foreland basin. We interpret the $\sim 1400-1300$ Ma detrital zircon population as continued sediment derived from cratonic sources, but the minor appearance of Andean zircons (Gondwanide and Cretaceous ages) in Cenozoic sediments suggests a transition to mixed Eastern Cordillera sediment contributions. 

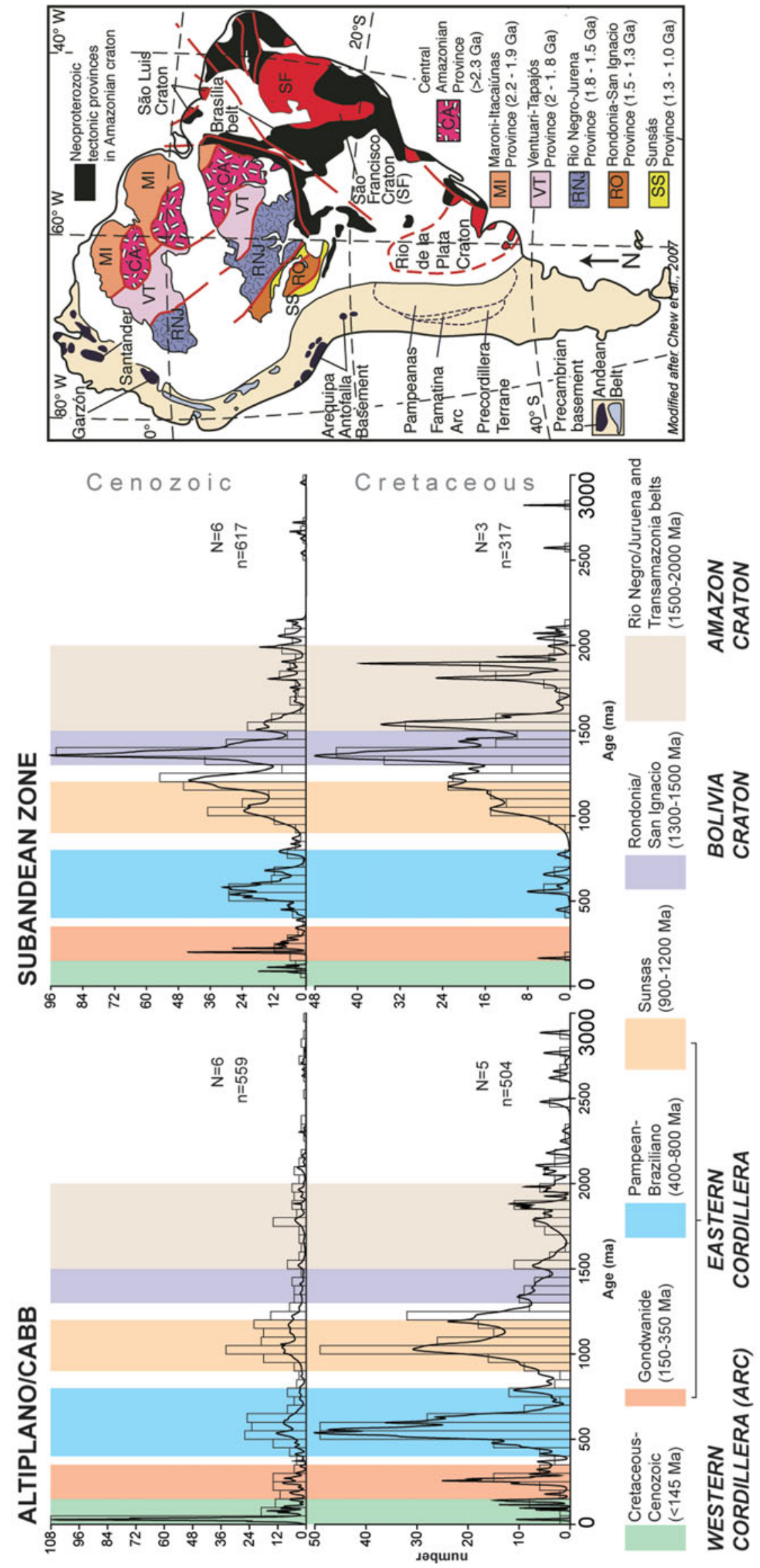

Figure 7. (Colour online) Comparison of U-Pb detrital zircon geochronologic analyses of Cretaceous through Cenozoic rocks from the Subandean Zone and Altiplano/CABB. Subandean rocks have strong cratonic signatures and lack Western Cordillera zircons (see map) whereas Altiplano/CABB rocks have strong Eastern and Western Cordillera provenance, but lack characteristic cratonic populations. 


\section{3.d. Thermochronology}

Apatite and zircon (U-Th)/He thermochronologic methods (AHe and $\mathrm{ZHe}$ ) constrain the timing of cooling below closure temperatures of $\sim 60^{\circ} \mathrm{C}$ and $\sim 180^{\circ} \mathrm{C}$, respectively, corresponding to crustal depths between $\sim 2$ and $6 \mathrm{~km}$ (Ehlers et al. 2005). In detail, closure temperatures correspond to a range of temperatures (partial retention zone, PRZ), above which $\mathrm{He}$ is not retained in the mineral and below which He retention is complete. For additional details regarding (U-Th)/He thermochronometry see existing reviews (Farley, 2002; Ehlers \& Farley, 2003; Reiners, 2005; Flowers et al. 2009). Cooling ages from samples collected over a range of elevations can provide constraints on exhumation rates and magnitudes. For our study in the Cordillera de Carabaya, we collected samples from elevations of 3710-4764 m above sea level (asl), including seven samples of medium-grained granodiorite and monzodiorite of the Permo-Triassic Coasa pluton along the Rio Achasiri and Rio Tambillo gorges and one sample of the Carboniferous Ambo Formation quartzite along the SW Coasa pluton margin. Three additional samples were collected from sandstones of the Cretaceous Vivian and Oriente formations in the Subandean Zone. At least three single grain aliquots were analysed from each sample. Samples can be characterized as reset, partially reset or non-reset. Reset samples have aliquot ages that cluster together and are younger than the depositional or intrusive age of the rock and are interpreted as exhumed from temperatures greater than the PRZ. Partially reset samples exhibit a range of individual grain aliquot ages potentially younger and older than the depositional age and are interpreted as exhumed from the PRZ. Non-reset samples display individual grain aliquot ages older than or equal to the depositional age and are interpreted to be exhumed from above the PRZ. A lack of correlation between effective $\mathrm{U}$ concentration $(\mathrm{eU})$ and age, as well as grain size and age, suggests that variations in He retention, grain composition and size do not significantly influence thermochronologic results (online Supplementary Material available at http://journals.cambridge.org/geo). Thus, we can more confidently interpret the presence or absence of PRZ in the data.

\section{3.d.1. Overview}

We report $\mathrm{AHe}$ and $\mathrm{ZHe}$ cooling ages to define the timing of exhumational cooling along the Subandean Zone (Fig. 8) and Cordillera de Carabaya (Figs 9, 10, 12,13). Seven ZHe samples from the Coasa pluton have Oligocene-middle Miocene mean sample ages. Eight AHe samples from the Coasa pluton reveal two clusters of late Oligocene and middle Miocene ages that are younger than the corresponding $\mathrm{ZHe}$ ages. Three AHe samples from the Subandean Zone have ages that decrease towards the foreland, suggesting onset of cooling by middle Miocene time. Although these new results provide constraints on the timing of exhumation of se-

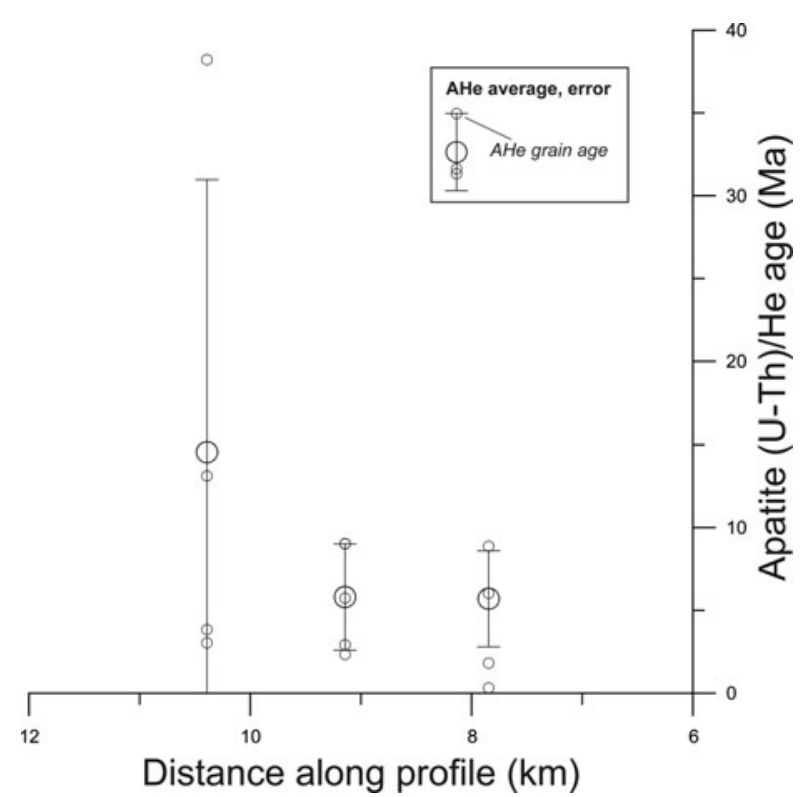

Figure 8. Age-distance relationship for apatite (U-Th)/He samples from Cretaceous sandstones in the Subandean Zone. Distance along profile is measured in kilometres from the frontal thrust (Fig. 1b), with foreland situated to the right and hinterland to the left. Average apatite (U-Th)/He age shown with $2 \sigma$ error.

lect structures, existing data do not permit calculation of precise shortening rates throughout the duration of Andean deformation.

\section{3.d.2. Subandean Zone}

The cooling histories of three samples from Cretaceous sandstones exposed in the Subandean Zone were determined using AHe thermochronology. The structurally shallowest sample situated towards the hinterland exhibits high uncertainty $(14.6 \pm 16.4 \mathrm{Ma})$ owing to individual grain ages of 3.0 Ma, 3.8 Ma, 13.1 Ma and 38.2 Ma. The large spread in grain ages may suggest the sample is partially reset. Two additional samples from structurally lower positions in the Cretaceous stratigraphy situated towards the foreland are more consistent, with ages of $5.8 \pm 3.2 \mathrm{Ma}$ and $5.7 \pm 2.9 \mathrm{Ma}$, respectively (Fig. 8) that we interpret as fully reset ages.

\section{3.d.3. Coasa pluton}

Seven samples were collected along a $\sim 20 \mathrm{~km}$ long transect in NE-trending incised canyons in the Coasa pluton. An additional sample was collected from Carboniferous Ambo Formation quartzite host rock $\sim 300 \mathrm{~m} \mathrm{SW}$ of the pluton contact (Fig. 9). All eight samples were analysed for $\mathrm{AHe}$, and seven were analysed for ZHe. Samples analysed for ZHe cooling ages span elevations between 4764 and $3710 \mathrm{~m}$ that increase to the SW. Mean ZHe sample ages range from $18.6 \pm 1.0 \mathrm{Ma}$ to $34.3 \pm 4.4 \mathrm{Ma}$ (Fig. 10). These ages plot along a single age versus elevation trend.

Eight AHe samples reveal two groups of ages. The two highest elevation samples have ages of $\sim 30$ and 26.5 Ma, and plot near the trend line defined by $\mathrm{ZHe}$ 


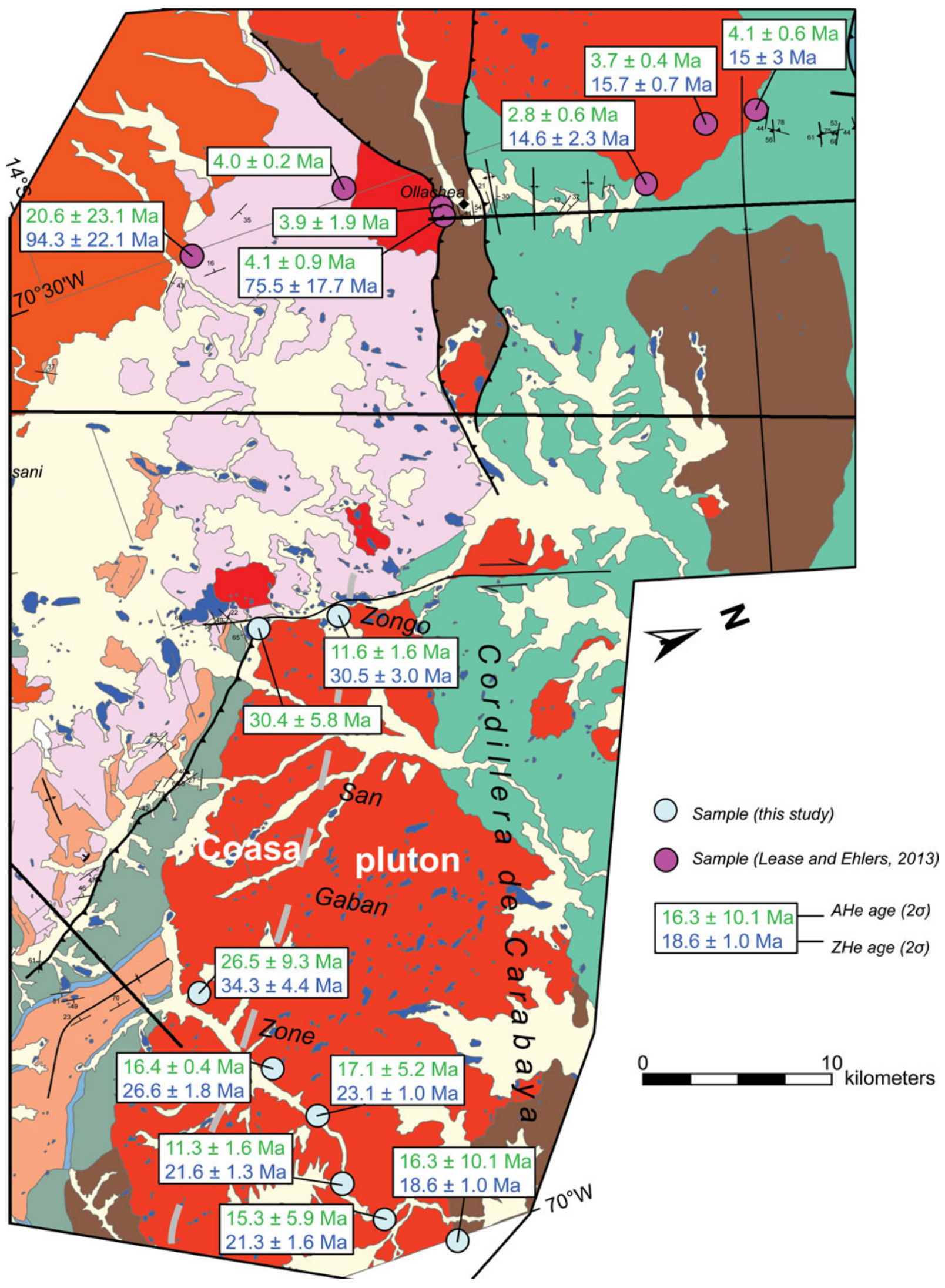

Figure 9. (Colour online) Geologic map of Cordillera de Carabaya showing location and ages of apatite and zircon (U-Th)/He samples from this study and Lease \& Ehlers (2013). Gray dashed line from Farrar et al. (1988) showing boundary of Zongo-San Gaban Zone. This boundary separates $>26 \mathrm{Ma}$ AHe ages to the south from $<\sim 17 \mathrm{Ma}$ ages to the north. Map units and symbols the same as Figure $1 b$. 
sample ages. The remaining six lower elevation AHe samples have ages between $\sim 17$ and $11 \mathrm{Ma}$, and fall along a similarly steep age elevation trend that is younger than the corresponding $\mathrm{ZHe}$ ages from the same samples (Fig. 10).

\section{Discussion}

\section{4.a. Inversion of pre-Andean normal faults}

Previous workers have shown segments of the Andes dominated by thin-skinned (Roeder, 1988; Kley, Gangui \& Kruger, 1996; Zapata \& Allmendinger, 1996; Baby et al. 1997; McQuarrie, 2002a), thick-skinned (Grier, Salfity \& Allmendinger, 1991; Kley \& Monaldi, 1998; Giambiagi et al. 2011) or hybrid thin- and thickskinned deformation (Jordan \& Allmendinger, 1986; Dengo \& Covey, 1993; Cooper et al. 1995; Roeder \& Chamberlain, 1995; Kley et al. 1997; Mora et al. 2006). Fault reactivation has been proposed for multiple segments of the Peruvian Andes (Hermoza et al. 2005; Scherrenberg, Holcombe \& Rosenbaum, 2014; Chapman et al. 2015; Eude et al. 2015) although fault geometries may vary. Field and map relationships enabled construction of a balanced cross-section and demonstrated the location of pre-Andean normal faults. These normal faults control some of the major changes in structural elevation, and contributed to a mix of thinand thick-skinned deformation. The restored crosssection demonstrates that the two main detachments are likely linked to rheology. Phanerozoic rocks detach at the basement-cover interface at $\sim 10 \mathrm{~km}$ and contributed to thin-skinned deformation. The deeper detachment accommodating motion of basement thrust sheets originated at $\sim 23-24 \mathrm{~km}$ depth, consistent with models of lithospheric strength profiles suggesting a strong upper crust situated above a weak middle and lower crust, e.g. Bürgmann \& Dresen (2008) and previous cross-sections (Chapman et al. 2015; Eude et al. 2015). Some of these basement-involved faults control thick-skinned deformation, or guided thin-skinned deformation.

We identify four pre-Andean normal faults selectively reactivated as thrust faults during Andean shortening (Fig. 11) defined by subcrop relationships and rapid sediment thickness changes across each fault. All examples preferentially preserve pre- or synrift rocks in hanging walls that were eroded or not deposited from the corresponding footwall. Thrust reactivation of the SW-dipping basement thrust B2 (Fig. 1c) is interpreted as the deeper segment of a pre-Andean normal fault that fed displacement into the backthrusts of the Eastern Cordillera. The NE-dipping basement thrust B3 is considered an inverted conjugate normal fault of B2, together defining a Triassic graben. The graben preserves $>6 \mathrm{~km}$ of upper Palaeozoic rocks and Triassic synrift Mitu Group deposits and suggests these two faults may have controlled rift evolution. Two Andean thrust faults from the $\mathrm{CABB}$ are interpreted as inverted pre-Andean normal faults, but thin accumulations of pre- or syn-

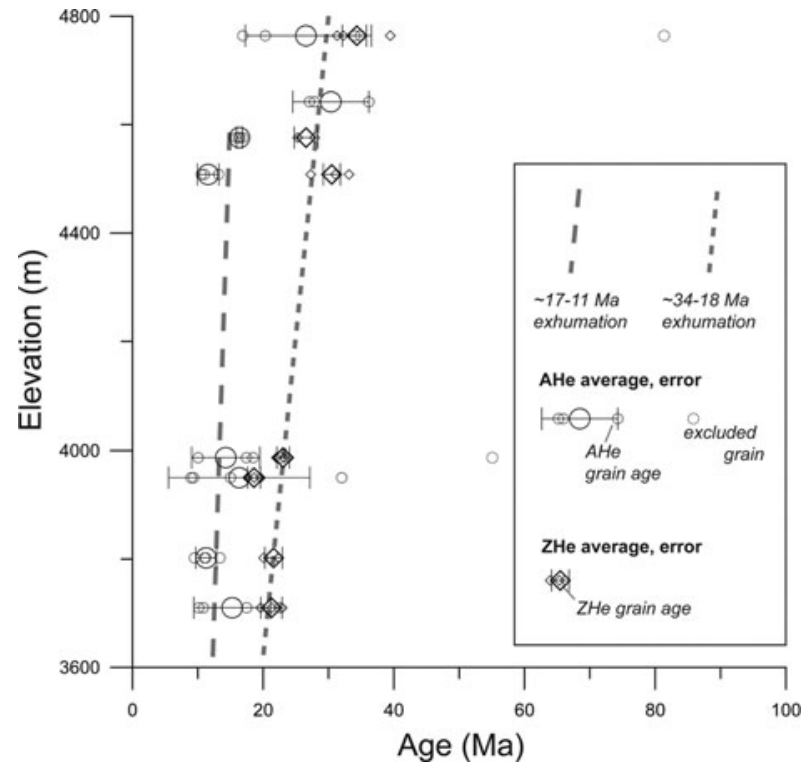

Figure 10. Elevation versus age plot of apatite and zircon (UTh)/He results from the Coasa pluton (see Fig. 9 for location). Short dashed line emphasizes trend among ZHe ages. Long dashed line emphasizes inflection point observed in AHe ages.

rift rocks suggest these are likely minor normal faults within the Triassic rift. Isolated exposures of Lower Carboniferous Ambo Group rocks from the Pz1 thrust hanging wall (Fig. 1c) are not observed across the fault in the corresponding footwall. The Ayaviri fault (AF, Fig. 1c) is also interpreted as an inverted pre-Andean normal fault because exposures of Triassic synrift Mitu Group deposits are common along strike in the Ayaviri fault hanging wall, but are not observed in the footwall.

The Macusani structural zone is interpreted as an inverted graben that subsided during Triassic rifting and Mitu Group deposition (Figs 1c, 11). A 3-4 km thick Carboniferous-Permian sequence in the Macusani structural zone is attributed to preservation in the subsiding graben. Equivalent deposits were likely eroded from the horst flanks. Some exposures of Mitu Group conglomerate deposits near the margins of the Macusani structural zone are composed of Permian limestone clasts, suggesting that erosion of Permian Copacabana Formation from the uplifted footwall was a primary sediment source.

Selective reactivation of these faults played key roles in the regional kinematic history. The B2 fault marks the NE limit of observed structural geometries inherited from pre-Andean deformational events. To the SW, inversion of the basement-involved B3 normal fault fed displacement upsection into the lower Palaeozoic and Cretaceous rocks of the CABB. The inherited orientation of the B3 fault was key in defining the location and vergence direction of the CABB. The Ayaviri fault is part of a larger fault system that persists for $\sim 400 \mathrm{~km}$ along strike (Sempere et al. 1990). If the entire length of the structure represents an inherited feature, the development of the Altiplano may be linked to reactivation of pre-Andean structures, or structures that nucleated from inherited basement structures. Each of these 


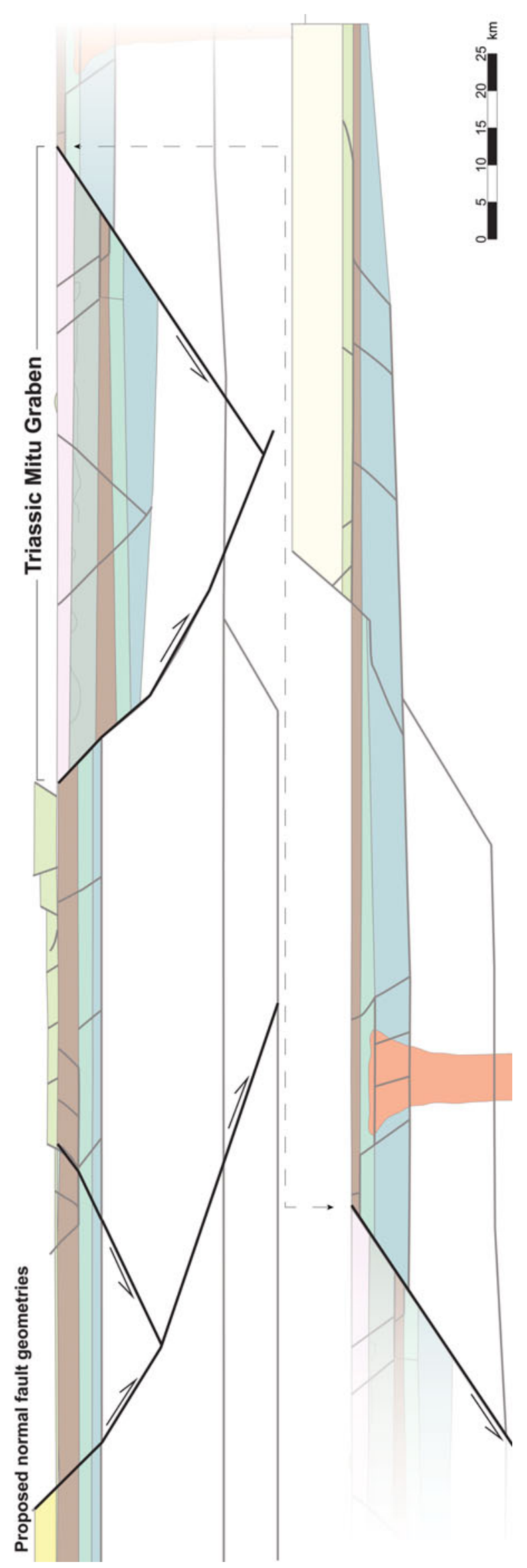

Figure 11. (Colour online) Restored cross-section overlain by proposed geometries for Triassic normal faults before reactivation during Cenozoic Andean shortening. structures marks a significant boundary between structural zones and is parallel to the modern Andean structural grain. Moderate fault dips were likely key to allowing inversion of these favourably oriented structures (Sibson, 1985, 1990). We suggest that reactivation of these inherited features contributed to structural compartmentalization of the Eastern Cordillera, establishing zones with distinct deformation styles such as the Macusani structural zone and the CABB (Giambiagi et al. 2011; Iaffa et al. 2011).

\section{4.b. Timing of deformation}

\section{4.b.1. Structural control on exhumation}

Thermochronology datasets constrain the timing of cooling due to erosion, rock uplift or post-igneous thermal relaxation. In actively shortening orogens that lack volcanic activity, thrust motion can promote topographic development and exhumational cooling (Farrar et al. 1988; Barnes et al. 2006, 2008; Gillis, Horton \& Grove, 2006; Ege et al. 2007; McQuarrie, Barnes \& Ehlers, 2008; Lease \& Ehlers, 2013; Eichelberger et al. 2013). We document exhumational cooling in the Coasa pluton and Subandean Zone using AHe and ZHe thermochronometers and integrate these with previous thermochronometer datasets.

Previous studies of the Coasa pluton and Cordillera de Carabaya identified a narrow zone (Zongo-San Gabán Zone) yielding discordant biotite and muscovite $\mathrm{K}-\mathrm{Ar}$ ages, and ${ }^{40} \mathrm{Ar}-{ }^{39} \mathrm{Ar}$ age spectra with biotite ${ }^{40} \mathrm{Ar}-{ }^{39} \mathrm{Ar}$ ages as young as $37 \pm 1 \mathrm{Ma}$ (Kontak et al. 1990). These data were interpreted as evidence for an Eocene phase of rapid heating attributed to burial by thick, potentially basement-involved, backthrust sheets (Martinez, 1980; Farrar et al. 1988) that is older than proposed $\sim 30-24$ Ma wedge advance in northern Peru (Eude et al. 2015). The structure that achieved this burial has not yet been identified. We suggest that reactivation of the basement-involved SW-dipping normal fault ('B2' in Fig. 1c) fed displacement forward to lower Palaeozoic rocks in the Eastern Cordillera. Motion on the EC1 backthrust (7.8 km thick lower Palaeozoic hanging wall) would have buried Cordillera de Carabaya plutons to a minimum $\sim 10-11 \mathrm{~km}$ depth. This does not incorporate an unknown, potentially $>$ $5 \mathrm{~km}$ thick, accumulation of post-Devonian to Eocene rocks possibly eroded from the Eastern Cordillera, which would increase burial depth to $\sim 15-16 \mathrm{~km}$. Assuming a $27^{\circ} \mathrm{C} \mathrm{km}^{-1} \pm 20 \%$ geothermal gradient (Barnes et al. 2006), burial by the EC1 backthrust (Fig. 1c) could sufficiently heat the Cordillera de Carabaya and Coasa plutons to the $350 \pm 50^{\circ} \mathrm{C}$ proposed previously (Farrar et al. 1988).

Previous workers have established a two-phase cooling history in the Cordillera Real of Bolivia, which occupies a structural position similar to the Cordillera de Carabaya in southern Peru. The first phase is cooling from 45-25 Ma with a second pulse from $17 \mathrm{Ma}$ to present (Gillis, Horton \& Grove, 2006). Our ZHe and 
AHe results reveal Oligocene to middle Miocene cooling of the Coasa pluton in the Cordillera de Carabaya (Fig. 10). We interpret all ZHe samples as reset. The lack of partially reset and non-reset samples is evidence for no PRZ, suggesting exhumation from depths greater than $\sim 6 \mathrm{~km}$. ZHe sample ages fall along a steep age versus elevation relationship that suggests the Coasa pluton cooled during rapid late Oligocene - early Miocene deformation in the Eastern Cordillera (Fig. 10). Late Oligocene ( $\sim 30$ and $26 \mathrm{Ma})$ and middle Miocene ( $\sim 17-11 \mathrm{Ma})$ AHe ages are spatially separated across the boundary to the Zongo-San Gabán Zone (Farrar et al. 1988). We interpret all samples as reset. Late Oligocene ages are from the highest elevation samples and plot along the age versus elevation trend defined by $\mathrm{ZHe}$ ages. The remaining lower elevation samples record $\mathrm{AHe}$ ages that are younger than their corresponding $\mathrm{ZHe}$ ages, but plot along a similar age versus elevation trend (Fig. 10).

We suggest that duplexing of Ordovician rocks at depth, driven by insertion of the B2 basement thrust sheet, is the structural driver for the first phase of exhumational cooling. This phase exhumed all samples above the ZHe PRZ to crustal levels such that the highest two elevation samples were above the $\mathrm{AHe}$ PRZ. Reactivation of the normal fault that controlled Mitu Graben subsidence during Triassic extension defines the B2 thrust sheet hanging wall, demonstrating the role of selective reactivation on exhumation of the Eastern Cordillera. Subsequent exhumation recorded by our $\mathrm{ZHe}$ and $\mathrm{AHe}$ results from the Coasa pluton is linked to movement translation over the B1 basement ramp that drove exhumation of the remaining six lower elevation AHe samples above the PRZ.

AHe results from Cretaceous rocks of the Subandean Zone are interpreted as a mix of partially reset and reset samples (Fig. 8). The two reset samples have ages of $5.8 \pm 3.2 \mathrm{Ma}$ and $5.7 \pm 2.9 \mathrm{Ma}$, are situated towards the foreland and come from structurally lower sections of the Cretaceous rocks. These two ages require onset of deformation by $\sim 6 \mathrm{Ma}$, but permit deformation onset as early as the partially reset sample age at $\sim 15 \mathrm{Ma}$ (Fig. 8). This is consistent with other workers who suggest Subandean Zone deformation in Bolivia and Peru did not initiate until after $25-20 \mathrm{Ma}$ (Horton, 2005; Barnes et al. 2006, 2008; Espurt et al. 2011; Eude et al. 2015). In general, we interpret middle to late Miocene AHe cooling ages from Cretaceous rocks in the Subandean Zone as thrust-related exhumational cooling initiated by middle Miocene time. Because deformation into the Subandean Zone is fed by displacement on the B1 fault, these ages also place constraints on the timing of motion of this basement thrust sheet. However, these results do not permit resolving the precise onset or rate of Subandean shortening.

\section{4.b.2. Along-strike variations in exhumation}

Here we compare our $\mathrm{ZHe}$ and AHe results from the Coasa pluton with samples collected from similar li-

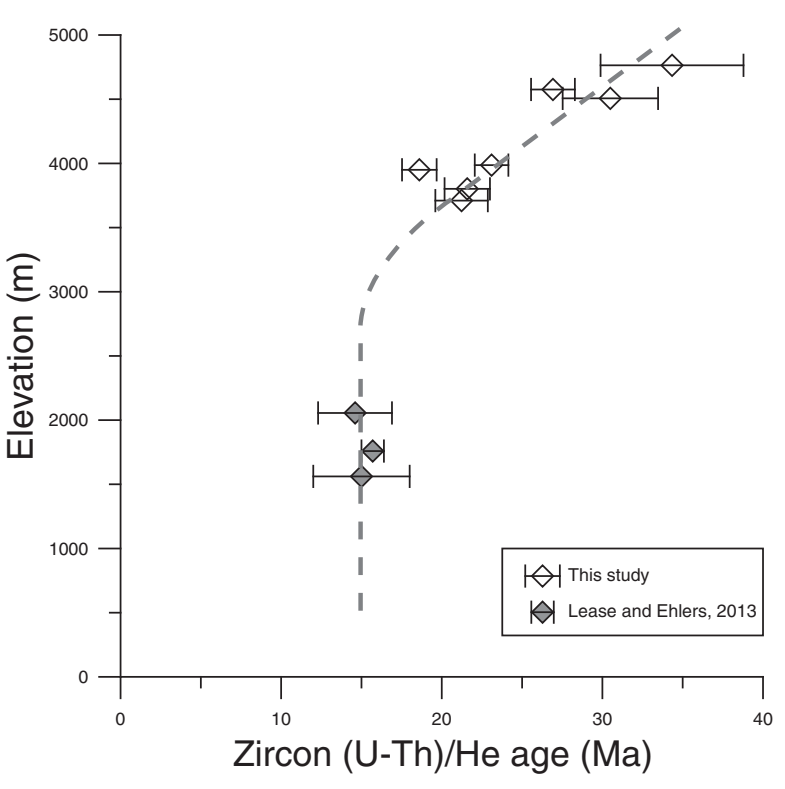

Figure 12. Elevation versus age relationship combing ZHe results from this study and Lease \& Ehlers (2013). Note age of inflection point, suggesting $\sim 15$ Ma rapid cooling.

thologies and structural levels but at lower elevations from the Rio San Gabán transect $\sim 40 \mathrm{~km} \mathrm{NW}$ along strike (Lease \& Ehlers, 2013) (Fig. 9). As such, this comparison helps define along-strike patterns in exhumation and reveals potential elevation controls on thermochronologic ages.

ZHe results from the Coasa pluton and Rio San Gabán transect define an age versus elevation relationship with an inflection point at $\sim 15-16 \mathrm{Ma}$ (Fig. 12). We interpret this as potentially synchronous, structurally driven exhumation along strike through the ZHe PRZ. Initial interpretations from the age versus elevation relationship of our AHe data from the Coasa pluton is consistent with onset of rapid cooling at $\sim 15 \mathrm{Ma}$ (Fig. 10). However, results from $\sim 40 \mathrm{~km} \mathrm{NW}$ along strike demonstrate $\sim 4 \mathrm{Ma} \mathrm{AHe}$ ages (Lease \& Ehlers, 2013). Combining AHe results from both studies reveals an age versus elevation relationship that defines a younger inflection point at $\sim 4-5 \mathrm{Ma}$ (Fig. 13). Lease \& Ehlers (2013) interpreted $\sim 4 \mathrm{Ma}$ AHe cooling ages along the Rio San Gabán transect as evidence for focused incision driven by Pliocene climate change. Whereas the Rio San Gabán samples were collected at lower elevations from a deeply incised canyon, our Coasa pluton samples are situated at higher elevations at the edge of the Eastern Cordillera plateau. The Coasa pluton has not been affected by a similar magnitude of canyon incision as the Rio San Gabán transect. Clear age versus elevation relationships among our data and results from Lease \& Ehlers (2013) suggest a regional control on exhumation has persisted since Miocene time, although the driver remains debated.

Previous biotite and muscovite $\mathrm{K}-\mathrm{Ar}$ and ${ }^{40} \mathrm{Ar}-$ ${ }^{39} \mathrm{Ar}$ results from the Cordillera de Carabaya and Cordillera Real of Peru and Bolivia establish the onset of 


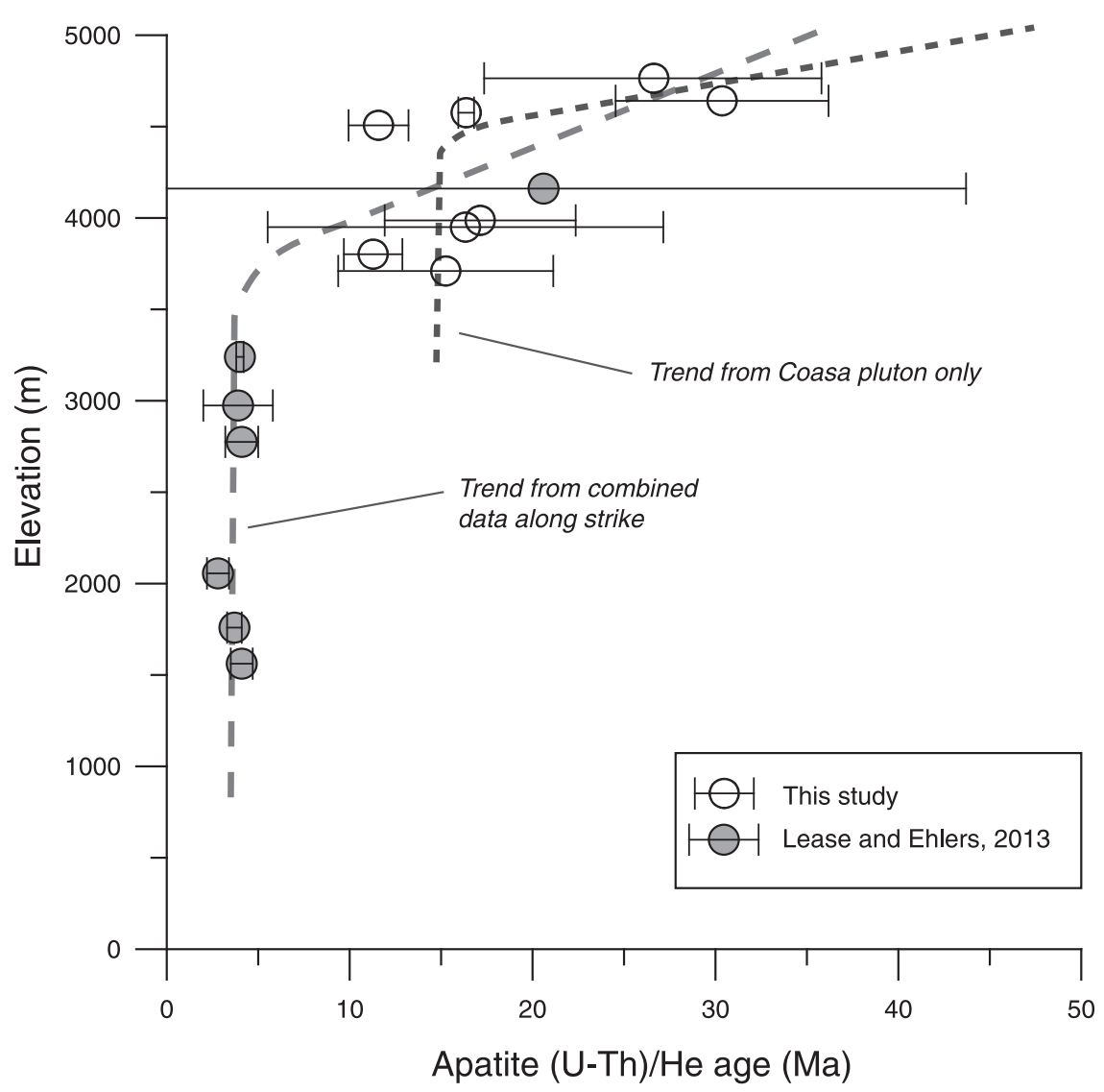

Figure 13. Elevation versus age relationship for AHe results from this study and Lease \& Ehlers (2013). Note age of inflection point for combined data is $\sim 4-5 \mathrm{Ma}$, whereas inflection point observed in Coasa pluton data (this study, Fig. 10) is less distinct.

exhumational cooling associated with deformation at 40-45 Ma (Benjamin, Johnson \& Naeser, 1987; Farrar et al. 1988; Gillis, Horton \& Grove, 2006; Barnes et al. 2006). We interpret the combined thermochronologic studies as evidence for protracted exhumation in the Eastern Cordillera since Eocene time. In our study area, exhumation is located at the edge of the Mitu Graben and driven by basement thrust sheets, some of which are defined by reactivated Triassic normal faults. This highlights the role of inherited structural framework on the temporal and spatial patterns of exhumation during subsequent orogenesis.

\section{4.b.3. Role of strike-slip deformation}

Our new thermochronologic results provide temporal constraints on the exhumation history associated with shortening in the Eastern Cordillera and Subandean Zone. The timing of potential strike-slip deformation remains poorly constrained. Our cross-section construction assumes minimal out-of-plane motion because we did not identify strike-slip faults in the study area. Counterclockwise (CCW) vertical axis rotations in southern Peru (northern limb of Bolivian orocline) determined from palaeomagnetic studies have been interpreted as evidence for significant Cenozoic strike-slip deformation (Roperch et al. 2006; Arriagada et al. 2008) and are critical for orocline reconstruction. Rousse et al. (2005) conducted a palaeomagnetic study of Miocene clastic deposits in the Ayaviri basin (Ayaviri fault footwall) that remains the only constraint within our study area. Complex demagnetization results are equivocal, suggesting either minor $\mathrm{CCW}$ rotation or post-depositional remagnetization. Those authors attributed vertical axis rotation to left-lateral strike-slip motion along the Ayaviri fault that they argue was kinematically linked to the left-lateral Cochabamba fault of Bolivia (Eichelberger \& McQuarrie, 2015). Whereas piercing points have not been identified demonstrating strike-slip offset of the Ayaviri fault, the timing and magnitude of late Oligocene reverse Ayaviri fault motion is constrained by footwall growth strata (Perez \& Horton, 2014) and our cross-section. The few additional strike-slip faults proposed in Peru are situated outside our study area and depicted as either parallel or oblique to Andean structural grain (Gilder et al. 2003; Rousse et al. 2005; Carlotto et al. 2006; Roperch et al. 2006; Arriagada et al. 2008; Mišković et al. 2009). Reconstructions suggest overlap between the timing of vertical axis rotations and exhumation in southern Peru, including fore-arc rotation before $\sim 25 \mathrm{Ma}$ (Roperch et al. 2006) and $\sim 18-5$ Ma rotations in the Eastern Cordillera (Rousse et al. 2005). Arriagada et al. (2008) used these rotations as support for significant Eocene-Oligocene age oroclinal bending of the forearc. Oroclinal bending of the Eastern Cordillera and Subandean Zone is notably less $\left(10-15^{\circ}\right)$ and more recent ( $\sim 15 \mathrm{Ma}$ to present) (Arriagada et al. 2008 ; 
Eichelberger \& McQuarrie, 2015). Although strikeslip faults are likely important to orocline kinematics in southern Peru, existing constraints support minimal strike-slip deformation within our study area.

\section{4.c. Pre-Andean structural control on Altiplano and Subandean basin provenance}

In addition to controlling the kinematic and exhumational history of the central Andes, the structural evolution of the Eastern Cordillera may have implications for basin evolution in the northern Altiplano. $\mathrm{U}-\mathrm{Pb}$ detrital zircon geochronologic results from the Cretaceous-Cenozoic stratigraphy preserved in the Altiplano/CABB and Subandean Zone show two key provenance differences. Cretaceous rocks from the Altiplano/CABB zone are characterized by Western and Eastern Cordillera provenance. In contrast, the Cretaceous rocks of the Subandean Zone show mostly cratonic (Rondonia/San Ignacio of Bolivia) affinities, and lack characteristic Western and Eastern Cordillera zircon populations, suggesting $\mathrm{W}$-directed sediment transport. The Cenozoic rocks of the Subandean Zone retain a dominant cratonic detrital zircon signal, with additional minor Eastern Cordillera contributions and no Cenozoic Western Cordillera arc detrital zircon ages. In contrast, Cenozoic Altiplano rocks are dominated by Cenozoic and Cretaceous (Western Cordillera arc) detrital zircons. The strong cratonic signal present in the Subandean Zone is different from the dominant Andean (Eastern/Western Cordillera) signal that characterizes the Altiplano/CABB. We investigate two potential palaeogeographic reconstructions that could contribute to these provenance records.

The first option mimics models proposed for the Central Andes of Bolivia (DeCelles \& Horton, 2003; Horton, 2012). This model suggests that development of a volcanic arc and an early fold-thrust belt created topography in the Western Cordillera during Cretaceous time (Chong, 1977; Vicente, 1990; Horton et al. 2002; Arriagada, Cobbold \& Roperch, 2006) and the flanking eastern foreland basin was partitioned by Eocene uplift of the Eastern Cordillera (Fig. 14a) (Benjamin, Johnson \& Naeser, 1987; Farrar et al. 1988; DeCelles \& Horton, 2003; McQuarrie et al. 2005; Gillis, Horton \& Grove, 2006). In this scenario, the Western Cordillera and South American craton would have been the main potential sources for detrital zircons during Cretaceous time, and the Eastern Cordillera could not have been a sediment source until exhumation in Eocene time.

The second scenario is similar to proposed palaeogeographic reconstructions of central and northern Peru and emphasizes two separate depocentres (West and East Peruvian troughs) separated by a structural high (Marañon geanticline) (Benavides-Caceres, 1956; Wilson, 1963; Dalmayrac, Laubacher \& Marocco, 1980; Mégard, 1984; Benavides-Caceres, 1999; Jaillard, Bengtson \& Dhondt, 2005; Scherrenberg et al. 2012) (Fig. 14b). Although the drivers and timing of the proposed structural high remain poorly constrained, it could have acted as a barrier to sediment transport, and been a sediment source throughout Cretaceous and Cenozoic deposition. The South America craton and Cretaceous-Cenozoic Western Cordillera rocks were also potential sediment sources throughout deposition.

Based on the strong Eastern Cordillera detrital zircon provenance signature present in the Cretaceous rocks of the Altiplano, we suggest the Eastern Cordillera may have had a topographic expression in Cretaceous time. Furthermore, the lack of distinctive zircon populations sourced from the Rondonia/San Ignacio craton in the Altiplano depocentres suggests W-directed palaeoflow was blocked from reaching the Altiplano, potentially by the Eastern Cordillera. Finally, the long-lived absence of Western Cordillera detrital zircons in the Subandean Zone can also be explained by the presence of the Eastern Cordillera that could have blocked Edirected palaeoflow. We interpret scenario two as a better candidate to explain our initial provenance records. This scenario may be at odds with the $\mathrm{K}-\mathrm{Ar}$ and ${ }^{40} \mathrm{Ar}-{ }^{39} \mathrm{Ar}$ thermochronologic datasets from the Eastern Cordillera, which demonstrate Eocene exhumation from $\sim 10 \mathrm{~km}$ depths. To satisfy both the provenance and thermochronologic datasets requires that the Eastern Cordillera plutons remained at $\sim 10 \mathrm{~km}$ depths until Eocene time. This requires the presence of a similarly thick total accumulation of Triassic Mitu Group, Jurassic and Cretaceous deposits in the Eastern Cordillera. Inversion and erosion of this Jurassic depocentre may explain the anomalous absence of Jurassic deposits in southern Peru, despite their presence throughout the rest of Peru (Rosas, Fontbote \& Tankard, 2007).

The structural framework and along-strike correlation of the proposed topographic boundary is unclear. In central Peru, the proposed Marañon high is flanked to the west by the Eocene E-vergent Marañon fold-thrust belt (Mégard, 1984), whereas an equivalent structural setting has not been demonstrated in southern Peru. One potential scenario could be that a persistent rift shoulder inherited from the Triassic rift that controlled Mitu Group deposition created a topographic barrier that blocked sediment transport between the Altiplano and Subandean depocentres. Alternatively, minor Early Cretaceous inversion of Triassic normal faults could have created a topographic barrier responsible for provenance variations between the two depocentres. Penetrative foliation observed in some Triassic Mitu Group deposits (Fig. 5) but not observed in overlying Cretaceous rocks of the $\mathrm{CABB}$ also suggests poorly constrained compression before Cretaceous time.

\section{Conclusions}

(1) Total shortening of $130 \mathrm{~km}(38 \%)$ was constrained from balanced cross-section construction across the Eastern Cordillera and Subandean Zone from southern Peru. This estimate is consistent with total shortening estimates from transects near Cusco, and less than 


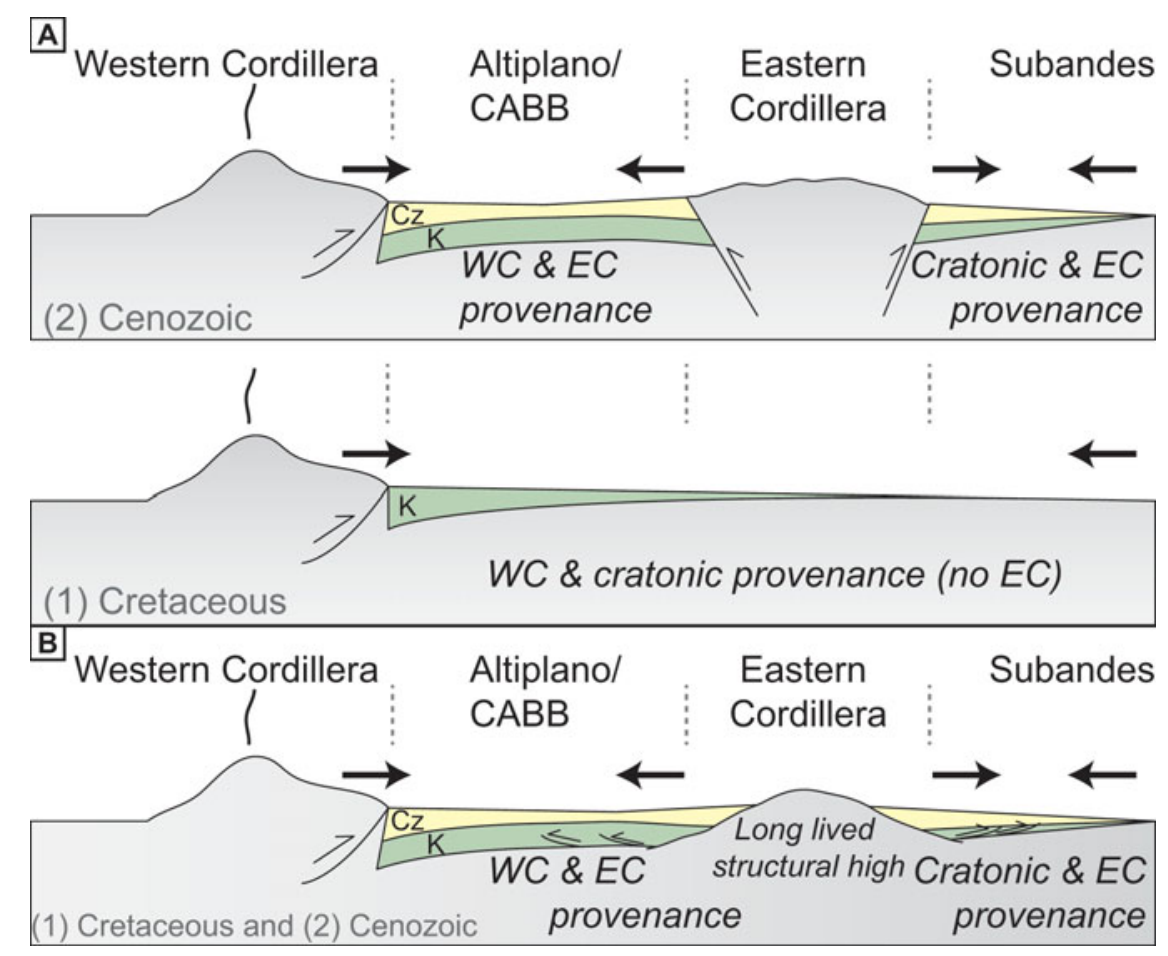

Figure 14. (Colour online) Two potential scenarios to explain provenance variation between the Altiplano/CABB and Subandean Zone. Scenario (a) represents a two-phase development of the foreland and hinterland basins proposed for Bolivia. In Cretaceous time, the Eastern Cordillera had not developed, and the two basins were contiguous. Cenozoic uplift of the Eastern Cordillera partitioned the contiguous basin into separate hinterland and foreland depocentres. The resulting provenance record would suggest similar sediment sources for Cretaceous deposits, but Cenozoic rocks would reflect unique provenance signatures for each basin after Eastern Cordillera uplift. Scenario (b) is similar to what has been proposed for central and northern Peru with a long-lived structural high. This suggests that a proto-Eastern Cordillera always separated the hinterland and foreland depocentres. The resulting provenance record would suggest sediment sources unique to each depocentre.

estimates in northern Bolivia, thus is broadly consistent with the proposed northward decrease in total shortening of the central Andes.

(2) Structural compartmentalization of the Eastern Cordillera is linked to reactivation of inherited Triassic normal faults. Preferential vergence direction of structures within the $\mathrm{CABB}$ is linked to the orientation of an inverted Triassic normal fault.

(3) Zircon (U-Th)/He ages from the Coasa pluton in the Eastern Cordillera are reset and record cooling ages between $\sim 34$ and $18 \mathrm{Ma}$. Apatite (U-Th)/He ages from the Coasa pluton are reset and reveal a group of late Oligocene and middle Miocene ages that are spatially separated by the Zongo-San Gaban boundary.

(4) Apatite (U-Th)/He ages demonstrate cooling in the Subandean Zone had initiated by $\sim 6 \mathrm{Ma}$ and possibly as early as $\sim 15 \mathrm{Ma}$.

(5) By identifying inverted pre-Andean normal faults, we define the Mitu Graben and propose a mechanism to explain thermochronologic records of Eocene burial by thrust sheets and exhumation in the Eastern Cordillera. Continued interaction with basement ramps likely controlled the Eocene to Miocene exhumation history.

(6) Combining our $\mathrm{ZHe}$ and $\mathrm{AHe}$ ages with previously reported results from Lease \& Ehlers (2013) reveals age versus elevation relationships that are consistent with protracted exhumation in the Eastern Cor- dillera, likely linked to continued shortening initiated at the margin of the Mitu Graben since Eocene time.

(7) A comparison of U-Pb detrital zircon geochronologic analyses records protracted Eastern and Western Cordillera sediment contribution to the Altiplano/CABB basins. In contrast, Subandean rocks preserve a dominant cratonic detrital signal, with a minor Andean detrital signal appearing only during Cenozoic time. This may reflect a long-lived structural high in the Eastern Cordillera that partitioned two depocentres and blocked mixing of zircon populations from the Western Cordillera or craton, or may reflect variable sediment contribution signatures from the margins of a large continuous foreland basin.

Acknowledgements. This research was supported by a National Science Foundation (NSF) grant (B.K.H., EAR0908518), (N.M. EAR-0908972), (T.A.E. EAR-0907817), NSF Graduate Research Fellowship (N.D.P.), ExxonMobil Geoscience Grant (N.D.P.), Geological Society of America Graduate Student Research Grant (N.D.P.), American Association of Petroleum Geologists Grants-in-Aid (N.D.P.), and support from the Jackson School of Geosciences at the University of Texas at Austin. Franco Bedoya and family were instrumental in logistical assistance and success in Peru. The staff at the University of Arizona LaserChron Center is thanked for their assistance with U-Pb geochronology. This manuscript benefited from discussions with K. Constenius, S. Gulick, M. Helper, R. Marrett, A. Mora, D. Stockli and 
A. Teixell. We appreciate comments and critiques from Michel Sébrier and an anonymous reviewer that improved the quality of the manuscript.

\section{Supplementary material}

To view supplementary material for this article, please visit http://dx.doi.org/10.1017/S0016756816000121.

\section{References}

ALLMENDINGER, R. W. 1986. Tectonic development, southeastern border of the Puna plateau, northwestern Argentine Andes. Geological Society of America Bulletin 97, 1070-82.

Allmendinger, R. W., FigueroA, D., Snyder, D., BeER, J., MPODOZIS, C. \& ISACKS, B. L. 1990. Foreland shortening and crustal balancing in the Andes at $30^{\circ} \mathrm{S}$ latitude. Tectonics 9, 789-809.

Allmendinger, R. W. \& Gubbels, T. 1996. Pure and simple shear plateau uplift, Altiplano-Puna, Argentina and Bolivia. Tectonophysics 259, 1-13.

ALLMENDINGER, R. W., JORDAN, T. E, KAY, S. M. \& ISACKS, B. L. 1997. The evolution of the Altiplano-Puna plateau of the central Andes. Annual Review of Earth and Planetary Sciences 25, 139-74.

Allmendinger, R. W., RAMOS, V. A., Jordan, T. E., PALMA, M. \& IsACKS, B. L. 1983. Paleogeography and Andean structural geometry, northwest-Argentina. Tectonics $\mathbf{2}$, $1-16$.

Arriagada, C., Cobbold, P. R. \& Roperch, P. 2006. Salar de Atacama basin: a record of compressional tectonics in the central Andes since the mid-Cretaceous. Tectonics 25, TC1008, doi: 10.1029/2004TC001770.

Arriagada, C., Roperch, P., Mpodozis, C. \& CobBold, P. R. 2008. Paleogene building of the Bolivian Orocline: tectonic restoration of the central Andes in 2-D map view. Tectonics 27, TC6014, doi: $10.1029 / 2008$ TC002269.

BABEyKo, A. Y. \& SoboleV, S. V. 2005. Quantifying different modes of the late Cenozoic shortening in the central Andes. Geology 33, 621-4.

BABY, P., RIVADENEIRA, M., BARRAGAN, R. \& ChristophOUL, F. 2013. Thick-skinned tectonics in the Oriente foreland basin of Ecuador. In Thick-SkinDominated Orogens: From Initial Inversion to Full Accretion (eds M. Nemčok, A. Mora \& J. W. Cosgrove), pp. 59-76. Geological Society of London, Special Publication no. 377.

Baby, P., Rochat, P., Mascle, G. \& Herail, G. 1997. Neogene shortening contribution to crustal thickening in the back arc of the Central Andes. Geology 25, 883-6.

Baby, P., Sempere, T., Oller, J. \& Herail, G. 1992. Evidence for major shortening on the eastern edge of the Bolivian Altiplano - the Calazaya Nappe. Tectonophysics 205, 155-69.

Bahlburg, H., Carlotto, V. \& Cardenas, J. 2006. Evidence of Early to Middle Ordovician arc volcanism in the Cordillera Oriental and Altiplano of southern Peru, Ollantaytambo Formation and Umachiri beds. Journal of South American Earth Sciences 22, 52-65.

Bahlburg, H., Vervoort, J. D., DuFrane, S. A., Carlotto, V., Reimann, C. \& Cardenas, J. 2011. The $\mathrm{U}-\mathrm{Pb}$ and $\mathrm{Hf}$ isotope evidence of detrital zircons of the Ordovician Ollantaytambo Formation, southern Peru, and the Ordovician provenance and paleogeography of southern Peru and northern Bolivia. Journal of South American Earth Sciences 32, 196-209.

Bally, A. W., Gordy, P. L. \& Stewart, G. A. 1966. Structure, seismic data, and orogenic evolution of southern Canadian Rocky Mountains. Bulletin of Canadian Petroleum Geology 14, 337-81.

BARAZANGI, M. \& ISACKS, B. L. 1976. Spatial-distribution of earthquakes and subduction of Nazca plate beneath South America. Geology 4, 686-92.

Barnes, J. B., Ehlers, T. A., Insel, N., McQuarrie, N. \& Poulsen, C. J. 2012. Linking orography, climate, and exhumation across the central Andes. Geology 40, $1135-8$.

BARNES, J. B., Ehlers, T. A., MCQuARrie, N., O'Sullivan, P. B. \& Pelletier, J. D. 2006. Eocene to recent variations in erosion across the central Andean foldthrust belt, northern Bolivia: implications for plateau evolution. Earth and Planetary Science Letters 248, 118-33.

Barnes, J. B., Ehlers, T. A., McQuarrie, N., O'Sullivan, P. B. \& TAWACKOLI, S. 2008. Thermochronometer record of central Andean plateau growth, Bolivia $\left(19.5^{\circ} \mathrm{S}\right)$. Tectonics 27, TC3003, doi: 10.1029/2007TC002174.

Bayona, G., Cortes, M., Jaramillo, C., OJedA, G., Aristizabal, J. J. \& REYes-Harker, A. 2008. An integrated analysis of an orogen-sedimentary basin pair: latest Cretaceous-Cenozoic evolution of the linked Eastern Cordillera orogen and the Llanos foreland basin of Colombia. Geological Society of America Bulletin 120, 1171-97.

BEACH, A. 1981. Some observations on the development of thrust faults in the Ultradauphinois Zone, French Alps. In Thrust and Nappe Tectonics (eds K. McClay \& N. J. Price), pp. 329-34. Geological Society of London, Special Publication no. 9.

Beck, R. A., Burbank, D. W., SERcombe, W. J., Riley, G. W., BARNDT, J. K., BERRY, J. R., AFZAL, J., KHAN, A. M., Jurgen, H., Metje, J., Cheema, A., Shafique, N. A., LAWRENCE, R. D. \& Khan, M. A. 1995. Stratigraphic evidence for an early collision between northwest India and Asia. Nature 373 (6509), 55-8.

BECK, S. L. \& ZANDT, G. 2002. The nature of orogenic crust in the central Andes. Journal of Geophysical Research 107, 2230, doi: 10.1029/2000JB000124.

BENAVIDES-CACERES, V. 1956. Cretaceous system in northern Peru. Bulletin of the American Museum of Natural History 108, 353-494.

BENAVIDES-CACERES, V. 1999. Orogenic evolution of the Peruvian Andes: the Andean Cycle. In Geology and Ore Deposits of the Central Andes (ed. B. J. Skinner), pp. 61-107. Society of Economic Geologists, Inc., Special Publication no. 7.

Benjamin, M. T., Johnson, N. M. \& NAEser, C. W. 1987. Recent rapid uplift in the Bolivian Andes - evidence from fission-track dating. Geology 15, 680-3.

Boekhout, F., Sempere, T., Spikings, R. \& Schaltegger, U. 2013. Late Paleozoic to Jurassic chronostratigraphy of coastal southern Peru: temporal evolution of sedimentation along an active margin. Journal of South American Earth Sciences 47, 179-200.

BOYER, S. E. \& ElliotT, D. 1982. Thrust systems. American Association of Petroleum Geologists Bulletin 66, 1196230.

BÜrgmann, R. \& DResen, G. 2008. Rheology of the lower crust and upper mantle: evidence from rock mechanics, geodesy, and field observations. Annual Review of Earth and Planetary Sciences 36, 531-67. 
BUTLER, R. W. H. 1989. The influence of pre-existing basin structure on thrust system evolution in the Western Alps. In Inversion Tectonics (eds M. A. Cooper \& G. D. Williams), pp. 105-22. Geological Society of London, Special Publication no. 44.

Butler, R. W. H., Tavarnelli, E. \& Grasso, M. 2006. Structural inheritance in mountain belts: an AlpineApennine perspective. Journal of Structural Geology 28, 1893-908.

CAHILL, T. \& IsACKS, B. L. 1992. Seismicity and shape of the subducted Nazca plate. Journal of Geophysical Research-Solid Earth 97 (B12), 17503-29.

Callot, P., OdOnNe, F. \& SEMPERE, T. 2008. Liquification and soft-sediment deformation in a limestone megabreccia: the Ayabacas giant collapse, Cretaceous, southern Peru. Sedimentary Geology 212, 49-69.

Callot, P., Sempere, T., Odonne, F. \& Robert, E. 2008. Giant submarine collapse of a carbonate platform at the Turonian-Coniacian transition: the Ayabacas Formation, southern Peru. Basin Research 20, 33357.

CARlotto, V. 2013. Paleogeographic and tectonic controls on the evolution of Cenozoic basins in the Altiplano and Western Cordillera of southern Peru. Tectonophysics 589, 195-219.

Carlotto, V., Tintaya, D., CÁrdenas, J., Carlier, G. \& RodRíGUEZ, R. 2006. Fallas transformates PermoTriásicas: La falla Patacancha-Tamburco (sur del Perú). In Resúmenes Extendidos XIII Congreso Peruano de Geología, Lima, 17-20 Octubre 2006 (ed. Sociedad Geológica del Perú - SGP), pp. 256-8.

Carrera, N., Munoz, J. A., Sabat, F., Mon, R. \& Roca, E. 2006. The role of inversion tectonics in the structure of the Cordillera Oriental (NW Argentinean Andes). Journal of Structural Geology, 28, 1921-32.

Chapman, A. D., Ducea, M. N., MCQuarrie, N., Coble, M., Petrescu, L. \& Hoffman, D. 2015. Constraints on plateau architecture and assembly from deep crustal xenoliths, northern Altiplano (SE Peru). Geological Society of America Bulletin 127, 1777-97.

Chew, D. M., Magna, T., KiRKLAND, C. L., MišKović, A., CArdona, A., Spikings, R. \& Schaltegger, U. 2008. Detrital zircon fingerprint of the Proto-Andes: evidence for a Neoproterozoic active margin? Precambrian Research 167, 186-200.

Chew, D. M., Schaltegger, U., Kosler, J., Whitehouse, M. J., Gutjahr, M., Spikings, R. A. \& Miskovic, A. 2007. U-Pb geochronologic evidence for the evolution of the Gondwanan margin of the north-central Andes. Geological Society of America Bulletin 119, 697711.

ChONG, G. 1977. Contribution to the knowledge of the Domeyko Range in the Andes of northern Chile. Geologische Rundschau 66, 374-404.

Clark, A. H., Farrar, E., KontaK, D. J., Langridge, R. J., Arenas, F., M. J., France, L. J., McBride, S. L., WoOdman, P. L., WASTENEYs, H. A., SANDEMAN, H. A. \& ARCHIBALD, D. A. 1990. Geologic and geochronological constraints on the metallogenic evolution of the Andes of southeastern Peru. Economic Geology 85, 1520-83.

Cooper, M. A., Addison, F. T., Alvarez, R., Coral, M., Graham, R. H., HaYWARD, A. B., Howe, S., MARTINEZ, J., NaAr, J., Peñas, R., Pulham, A. J. \& TABorda, A. 1995. Basin development and tectonic history of the Llanos basin, Eastern Cordillera, and middle Magdalena Valley, Colombia. American Association of Petroleum Geologists Bulletin 79, 1421-43.
Cordani, U. G., Sato, K., Teixeira, W., Tassinari, C. C. G. \& BASEI, M. A. S. 2000. Crustal evolution of the South American platform. In Tectonic Evolution of South America: 31st International Geological Congress, Rio de Janeiro, Brazil (eds U. G. Cordani, E. J. Milani, A. Thomaz Filho \& D. A. Campos), pp. $19-40$.

DAhlstrom, C. D. A. 1969. Balanced cross sections. Canadian Journal of Earth Sciences 6, 407-39.

Dalmayrac, B., LaUbacher, G. \& Marocco, R. 1980. Geologie des Andes Peruviennes. Paris: Travaux et Documents de L'ORSTOM no. 122, 501 pp.

DeCelles, P. G. \& Horton, B. K. 2003. Early to middle Tertiary foreland basin development and the history of Andean crustal shortening in Bolivia. Geological Society of America Bulletin 115, 58-77.

Decou, A., Von Eynatten, H., Dunkl, I., Frei, D. \& WORNER, G. 2013. Late Eocene to Early Miocene Andean uplift inferred from detrital zircon fission track and $\mathrm{U}-\mathrm{Pb}$ dating of Cenozoic forearc sediments (15-18 degrees S). Journal of South American Earth Sciences 45 , 6-23.

Dengo, C. A. \& Covey, M. C. 1993. Structure of the Eastern Cordillera of Colombia - implications for trap styles and regional tectonics. American Association of Petroleum Geologists Bulletin 77, 1315-37.

DEWEY, J. F. 1988. Extensional collapse of orogens. Tectonics 7, 1123-39.

Dickinson, W. R. \& Gehrels, G. E. 2003. U-Pb ages of detrital zircons from Permian and Jurassic eolian sandstones of the Colorado Plateau, USA: paleogeographic implications. Sedimentary Geology 163, $29-66$

DunN, J. F., HARTSHORN, K. G. \& HARTSHORN, P. W. 1995. Structural styles and hydrocarbon potential of the Subandean thrust belt of southern Bolivia. In Petroleum Basins of South America (eds A. J. Tankard, R. Suarez \& H. J. Welsink), pp. 523-43. American Association of Petroleum Geologists Memoir no. 62.

Ege, H., Sobel, E. R., Scheuber, E. \& Jacobshagen, V. 2007. Exhumation history of the southern Altiplano plateau (southern Bolivia) constrained by apatite fissiontrack thermochronology. Tectonics 26, TC1004, doi: 10.1029/2005TC001869.

Ehlers, T. A., Chaudhri, T., Kumar, S., Fuller, C. W., Willett, S. D., Ketcham, R., Brandon, M. T. Belton, D., Kohn, B., Gleadow, A. J., Dunai, T. \& Fu, F. 2005. Computational tools for low-temperature thermochronometer interpretation. Reviews in Mineralogy and Geochemistry 58, 589-622.

EHLERS, T. A. \& FARLEY, K. A. 2003. Apatite (U-Th)/He thermochronometry: methods and applications to problems in tectonic and surface processes. Earth and Planetary Science Letters 206, 1-14.

Ehlers, T. A. \& Poulsen, C. J. 2009. Influence of Andean uplift on climate and paleoaltimetry estimates. Earth and Planetary Science Letters 281, 238-48.

EICHELBERGER, N. \& MCQUARRIE, N. 2015. Kinematic reconstruction of the Bolivian orocline. Geosphere 11, 445-62.

Eichelberger, N., MCQuarrie, N., Ehlers, T. A., EnkelmanN, E., Barnes, J. B. \& Lease, R. O. 2013. New constraints on the chronology, magnitude, and distribution of deformation within the central Andean orocline. Tectonics 32, 1432-53.

Elger, K., OnCKen, O. \& Glodny, J. 2005. Plateau-style accumulation of deformation: Southern Altiplano. Tectonics 24, TC4020, doi: 10.1029/2004TC001675. 
ELLIOTT, D. 1983. The construction of balanced crosssections. Journal of Structural Geology 5, 101.

Espurt, N., Barbarand, J., Roddaz, M., Brusset, S., Baby, P., Saillard, M. and Hermoza, W. 2011. A scenario for late Neogene Andean shortening transfer in the Camisea Subandean zone (Peru, $12^{\circ} \mathrm{S}$ ): implications for growth of the northern Andean Plateau. Geological Society of America Bulletin 123, 2050-68.

Eude, A., Roddaz, M., Brichau, S., Brusset, S., Calderon, Y., Baby, P. \& Soula, J. C. 2015. Controls on timing of exhumation and deformation in the northern Peruvian eastern Andean wedge as inferred from low-temperature thermochronology and balanced cross section. Tectonics 34, 715-30.

FARLEY, K. A. 2002. (U-Th)/He dating: techniques, calibrations, and applications. In Noble Gases in Geochemistry and Cosmochemistry (eds P. D. Porcelli, C. J. Ballentine \& R. Wieler), pp. 819-43. Reviews in Mineralogy and Geochemistry, vol. 47.

Farrar, E., Clark, A. H., Kontak, D. J. \& Archibald, D. A. 1988. Zongo-San Gaban zone - Eocene foreland boundary of the Central Andean orogen, northwest Bolivia and southeast Peru. Geology 16, 55-8.

Fiorella, R. P., Poulsen, C. J., Pillco Zolá, R. S., BARNES, J., TABOR, C. \& EHLERS, T. A. 2015. Spatiotemporal variability of modern precipitation $\delta^{18} \mathrm{O}$ in the Central Andes and implications for paleoclimate and paloaltimetry estimates. Journal of Geophysical Research-Atmospheres 120, 463056.

Flowers, R. M., Ketcham, R. A., Shuster, D. L. \& FARLEY, K. A. 2009. Apatite (U-Th)/He thermochronometry using a radiation damage accumulation and annealing model. Geochimica et Cosmochimica Acta 73, 2347-65.

GARZione, C. N., Auerbach, D. J., SMith, J. J. S., RosArio, J. J., PASSEY, B. H., JORDAN, T. E. \& EILER, J. M. 2014. Clumped isotope evidence for diachronous surface cooling of the Altiplano and pulsed surface uplift of the Central Andes. Earth and Planetary Science Letters 393, 173-81.

Garzione, C. N., Hoke, G. D., Libarkin, J. C., Withers, S., MACFAdDEN, B., EILER, J., GHosh, P. \& Mulch, A. 2008. Rise of the Andes. Science 320, 1304-7.

GARZIONE, C. N., MOLNAR, P., LIBARKIN, J. C. \& MACFADDEN, B. J. 2006. Rapid late Miocene rise of the Bolivian Altiplano: evidence for removal of mantle lithosphere. Earth and Planetary Science Letters 241, 543-56.

GEHRELS, G. 2012. Detrital zircon U-Pb geochronology: current methods and new opportunities. In Tectonics of Sedimentary Basins: Recent Advances (eds C. Busby \& A. Azor), pp. 45-62. Chichester: John Wiley \& Sons, Ltd.

Ghosh, P., Garzione, C. N. \& Eiler, J. M. 2006. Rapid uplift of the Altiplano revealed through ${ }^{13} \mathrm{C}-{ }^{18} \mathrm{O}$ bonds in paleosol carbonates. Science 311, 511-5.

Giambiagi, L., Mescua, J., Bechis, F., Martinez, A. \& Folguera, A. 2011. Pre-Andean deformation of the Precordillera southern sector, southern Central Andes. Geosphere 7, 219-39.

GIL Rodriguez, W., BABY, P. \& BALlARD, J.-F. 2001. Structure et contrôle paléogéographique de la zone subandine péruvienne. Comptes Rendus de L'Academie des Sciences Serie Ii 333, 741-8.

Gilder, S., Rousse, S., Farber, D., McNulty, B., Sempere, T., Torres, V. \& Palacios, O. 2003. PostMiddle Oligocene origin of paleomagnetic rotations in
Upper Permian to Lower Jurassic rocks from northern and southern Peru. Earth and Planetary Science Letters 210, 233-48.

Gillis, R. J., Horton, B. K. \& Grove, M. 2006. Thermochronology, geochronology, and upper crustal structure of the Cordillera Real: implications for Cenozoic exhumation of the central Andean plateau. Tectonics 25, TC6007, doi: 10.1029/2005TC001887.

Gotberg, N., McQuarrie, N. \& Caillaux, V. C. 2010. Comparison of crustal thickening budget and shortening estimates in southern Peru $\left(12-14^{\circ} \mathrm{S}\right)$ : implications for mass balance and rotations in the 'Bolivian orocline'. Geological Society of America Bulletin 122 , $727-42$.

Grier, M. E., SAlfity, J. A. \& Allmendinger, R. W. 1991. Andean reactivation of the Cretaceous Salta rift, northwestern Argentina. Journal of South American Earth Sciences 4, 351-72.

GuBbels, T. L., IsACKS, B. L. \& FARRAR, E. 1993. Highlevel surfaces, plateau uplift, and foreland development, Bolivian Central Andes. Geology 21, 695-8.

Gunnell, Y., Thouret, J. C., Brichau, S., Carter, A. \& Gallagher, K. 2010. Low-temperature thermochronology in the Peruvian Central Andes: implications for long-term continental denudation, timing of plateau uplift, canyon incision and lithosphere dynamics. Journal of the Geological Society, London 167, 80315.

Hermoza, W., Brusset, S., Baby, P., Gil, W., Roddaz, M., Guerrero, N. \& Bolanos, M. 2005. The Huallaga foreland basin evolution: thrust propagation in a deltaic environment, northern Peruvian Andes. Journal of South American Earth Sciences 19, 21-34.

Hindle, D., Kley, J., OnCKen, O. \& SoboleV, S. V. 2005. Crustal balance and crustal flux from shortening estimates in the Central Andes. Earth and Planetary Science Letters 230, 113-24.

HorTON, B. K. 1998. Sediment accumulation on top of the Andean orogenic wedge: Oligocene to late Miocene basins of the Eastern Cordillera, southern Bolivia. Geological Society of America Bulletin 110, 1174-92.

HORTON, B. K. 1999. Erosional control on the geometry and kinematics of thrust belt development in the central Andes. Tectonics 18, 1292-304.

HORTON, B. K. 2005. Revised deformation history of the central Andes: inferences from Cenozoic foredeep and intermontane basins of the Eastern Cordillera, Bolivia. Tectonics 24, TC3011, doi: 10.1029/2003TC001619.

HORTON, B. K. 2012. Cenozoic evolution of hinterland basins in the Andes and Tibet. In Tectonics of Sedimentary Basins: Recent Advances (eds C. Busby \& A. Azor), pp. 427-44. Oxford, UK: Wiley-Blackwell.

Horton, B. K., HAMPtON, B. A. \& WAANDERS, G. L. 2001. Paleogene synorogenic sedimentation in the Altiplano plateau and implications for initial mountain building in the central Andes. Geological Society of America Bulletin 113, 1387-400.

Horton, B. K., Perez, N. D., Fitch, J. D. \& SaYlor, J. E. 2015. Punctuated shortening and subsidence in the Altiplano Plateau of southern Peru: implications for early Andean mountain building. Lithosphere 7, 117-37.

Horton, B. K., SAYlor, J. E., Nie, J. S., Mora, A., PARra, M., REYES-HARKER, A. \& STOCKLI, D. F. 2010. Linking sedimentation in the northern Andes to basement configuration, Mesozoic extension, and Cenozoic shortening: evidence from detrital zircon U-Pb ages, Eastern Cordillera, Colombia. Geological Society of America Bulletin 122, 1423-42. 
Horton, B. K., Yin, A., Spurlin, M. S., ZhOU, J. Y. \& WANG, J. H. 2002. Paleocene-Eocene syncontractional sedimentation in narrow, lacustrine-dominated basins of east-central Tibet. Geological Society of America Bulletin 114, 771-86.

IAfFa, N. D., SABAt, F., Bello, D., Ferrer, O., Mon, R. \& Gutierrez, A. A. 2011. Tectonic inversion in a segmented foreland basin from extensional to piggy back settings: the Tucuman basin in NW Argentina. Journal of South American Earth Sciences 31, 457-74.

Ibarra, I., Mamani, M., Rodriguez, R., Sempere, T., CARlotto, C. \& CARlier, G. 2004. Estratigrafia y tectónica de la parte sur de la cuenca de Ayaviri. In Nuevas Contribuciones del IRD y sus Contrapartes al Conocimiento Geológico del sur del Perú (eds J. Jacay \& T. Sempere), pp. 143-55. Publicacion Especial SGP No. 5. Lima: Sociedad Geologica del Peru - Institut de Recherché pour le Développement.

INGEMMET. 1999. Mapa Geologico del Peru, 1:1000000 Scale. Lima: Instituto Geologico y Metalurgico del Peru (INGEMMET).

INGEOMIN. 1975. Mapa Geologico del Peru. Lima: Instituto de Geologia y Mineria (INGEOMIN).

IsACKS, B. L. 1988. Uplift of the Central Andean plateau and bending of the Bolivian orocline. Journal of Geophysical Research-Solid Earth and Planets 93, 3211-31.

Jaillard, E., Bengtson, P. \& DHONDT, A. V. 2005. Late Cretaceous marine transgressions in Ecuador and northern Peru: a refined stratigraphic framework. Journal of South American Earth Sciences 19, 307-23.

JimeneZ, N., LOPEZ-VElasquEZ, S. \& SANTIVAÑEZ, R. 2009. Evolución tectonomagmática de los Andes Bolivianos. Revista de la Asociacion Geologica Argentina 65, 36-67.

JORDAN, T. E. 1995. Retroarc foreland and related basins. In Tectonics of Sedimentary Basins (eds C. J. Busby \& R. V. Ingersoll), pp. 331-62. Oxford: Blackwell Science.

Jordan, T. E. \& Allmendinger, R. W. 1986. The Sierras Pampeanas of Argentina - a modern analog of Rocky Mountain foreland deformation. American Journal of Science 286, 737-64.

Judge, P. A. \& Allmendinger, R. W. 2011. Assessing uncertainties in balanced cross sections. Journal of Structural Geology 33, 458-67.

KLEY, J. 1996. Transition from basement-involved to thinskinned thrusting in the Cordillera Oriental of southern Bolivia. Tectonics 15, 763-75.

Kley, J., Gangui, A. H. \& Kruger, D. 1996. Basementinvolved blind thrusting in the eastern Cordillera Oriental, southern Bolivia: evidence from cross-sectional balancing, gravimetric and magnetotelluric data. Tectonophysics 259, 171-84.

KLEY, J. \& Monaldi, C. R. 1998. Tectonic shortening and crustal thickness in the Central Andes: how good is the correlation? Geology 26, 723-6.

KLEY, J. \& MonALDI, C. R. 2002. Tectonic inversion in the Santa Barbara System of the central Andean foreland thrust belt, northwestern Argentina. Tectonics 21, 1061, doi: 10.1029/2002TC902003.

Kley, J., Monaldi, C. R. \& SAlfity, J. A. 1999. Alongstrike segmentation of the Andean foreland: causes and consequences. Tectonophysics 301, 75-94.

Kley, J., Muller, J., Tawackoli, S., Jacobshagen, V. \& Manutsoglu, E. 1997. Pre-Andean and Andeanage deformation in the Eastern Cordillera of Southern Bolivia. Journal of South American Earth Sciences 10, $1-19$.
Kley, J., Rossello, E. A., Monaldi, C. R. \& Habighorst, B. 2005. Seismic and field evidence for selective inversion of Cretaceous normal faults, Salta rift, northwest Argentina. Tectonophysics 399, 155-72.

KontaK, D. J., FARrar, E., Clark, A. H. \& ARChibald, D. A. 1990. Eocene tectonothermal rejuvenation of an upper Paleozoic-lower Mesozoic terrane in the Cordillera de Carabaya, Puno, southeastern Peru, revealed by $\mathrm{K}-\mathrm{Ar}$ and ${ }^{40} \mathrm{Ar}{ }^{39} \mathrm{Ar}$ dating. Journal of South American Earth Sciences 3, 231-46.

LAMB, S. \& HoKE, L. 1997. Origin of the high plateau in the Central Andes, Bolivia, South America. Tectonics 16, 623-49.

Laubacher, G. 1978. Geologie des Andes Peruviennes. Paris: Travaux et Documents de l'ORSTOM no. 95.

LAUBACHER, G. \& MÉGARD, F.1985. The Hercynian basement: a review. In Magmatism at A Plate Edge: The Peruvian Andes (ed. W. S. Pitcher, M. P. Atherton, E. J. Cobbing \& R. D. Beckinsale), pp. 29-37. New York: Halsted Press.

LAWTON, T. F. \& BRADFORD, B. A. 2011. Correlation and provenance of upper Cretaceous (Campanian) fluvial strata, Utah, USA, from zircon U-Pb geochronology and petrography. Journal of Sedimentary Research 81, 495-512.

LEASE, R. O. \& EHLERS, T. A. 2013. Incision into the Eastern Andean Plateau during Pliocene cooling. Science 341, 774-6.

LeIER, A., MCQUARrie, N., GARZIONE, C. \& EILER, J. 2013. Stable isotope evidence for multiple pulses of rapid surface uplift in the Central Andes, Bolivia. Earth and Planetary Science Letters 371, 49-58.

Loewy, S. L., ConNelly, J. N. \& DAlziel, I. W. D. 2004 An orphaned basement block: the Arequipa-Antofalla basement of the central Andean margin of South America. Geological Society of America Bulletin 116, 17187.

MARTINEZ, C. 1980. Structure et Evolution de la Chaîne Hercynienne et de la Chaîne Andine dans le Nord de la Cordillere des Andes de Bolivie, Géologie des Andes Boliviennes. Paris: Travaux et Documents de L'ORSTOM no. 119, $352 \mathrm{pp}$.

MarshaK, S., Karlstrom, K. \& Timmons, J. M. 2000. Inversion of Proterozoic extensional faults: an explanation for the pattern of Laramide and Ancestral Rockies intracratonic deformation, United States. Geology 28, $735-8$.

Mathalone, J. M. P. \& Montoya, R. M. 1995. Petroleum geology of the sub-Andean basins of Peru. In Petroleum Basins of South America (eds A. J. Tankard, R.S. Suárez \& H. J. Welsink), pp. 423-44. American Association of Petroleum Geologists Memoir no. 62.

MCBRIDE, S., RoBERTSON, R. \& CLARK, A. 1983. Magmatic and metallogenetic episodes in the northern tin belt, Cordillera Real, Bolivia. Geologische Rundschau 72, 685-713.

McGroder, M. F., Lease, R. O. \& Pearson, D. M. 2015. Along-strike variation in structural styles and hydrocarbon occurrences, Subandean fold-and-thrust belt and inner foreland, Colombia to Argentina. In Geodynamics of a Cordilleran Orogenic System: The Central Andes of Argentina and Northern Chile (eds P. G. DeCelles, M. N. Ducea, B. Carrapa \& P. A. Kapp), pp. 79-114. Geological Society of America Memoir no. 212.

MCQUARRIE, N. 2002a. The kinematic history of the central Andean fold-thrust belt, Bolivia: implications for building a high plateau. Geological Society of America Bulletin 114, 950-63. 
MCQUARRIE, N. 2002b. Initial plate geometry, shortening variations, and evolution of the Bolivian orocline. Geo$\log y$ 30, 867-70.

MCQuARRIE, N., BARNES, J. B. \& EHLERS, T. A. 2008. Geometric, kinematic, and erosional history of the central Andean Plateau, Bolivia $\left(15-17^{\circ} \mathrm{S}\right)$. Tectonics 27, TC3007, doi: 10.1029/2006TC002054.

MCQuARRIE, N. \& DECElles, P. 2001. Geometry and structural evolution of the central Andean backthrust belt, Bolivia. Tectonics 20, 669-92.

McQuarrie, N., Horton, B. K., Zandt, G., Beck, S. \& DeCELlES, P. G. 2005. Lithospheric evolution of the Andean fold-thrust belt, Bolivia, and the origin of the central Andean plateau. Tectonophysics 399, 1537.

MÉGARD, F. 1978. Etude Geologique des Andes du Perou Central. Paris: ORSTOM Memoirs No. 86.

MÉGARD, F. 1984. The Andean orogenic period and its major structures in central and northern Peru. Journal of the Geological Society, London 141(SEP), 893-900.

MÉGard, F., Dalmayrac, B., LaUbacher, G., Marocco, R., Martinez, C., Paredes, J. \& Tomasi, P. 1971. La Chaine Hercynienne au Perou et en Bolivie Premiers Resultats. Cahiers ORSTOM, Série Géologie 3 (1), pp. 5-44.

Menichetti, M., Lodolo, E. \& Tassone, A. 2008. Structural geology of the Fuegian Andes and Magallanes foldand-thrust belt - Tierra del Fuego Island. Geologica Acta 6, 19-42.

Mescua, J. F., Giambiagi, L. B., Tassara, A., Gimenez, M. \& RAMOS, V. A. 2014. Influence of pre-Andean history over Cenozoic foreland deformation: structural styles in the Malargüe fold-and-thrust belt at $35^{\circ} \mathrm{S}$, Andes of Argentina. Geosphere 10, 585-609.

MišKović, A. \& SCHALTEGGER, U. 2009. Crustal growth along a non-collisional cratonic margin: a Lu-Hf isotopic survey of the Eastern Cordilleran granitoids of Peru. Earth and Planetary Science Letters 279, 303-15.

MišKović, A., Spikings, R. A., CHew, D. M., Kosler, J., Ulianov, A. \& Schaltegger, U. 2009. Tectonomagmatic evolution of Western Amazonia: geochemical characterization and zircon $\mathrm{U}-\mathrm{Pb}$ geochronologic constraints from the Peruvian Eastern Cordilleran granitoids. Geological Society of America Bulletin 121, 1298324.

Monaldi, C. R., Salfity, J. A. \& Kley, J. 2008. Preserved extensional structures in an inverted Cretaceous rift basin, northwestern Argentina: outcrop examples and implications for fault reactivation. Tectonics 27, TC1011, doi: 10.1029/2006TC001993.

Mora, A., Parra, M., Strecker, M. R., Kammer, A., Dimate, C. \& Rodriguez, F. 2006. Cenozoic contractional reactivation of Mesozoic extensional structures in the Eastern Cordillera of Colombia. Tectonics 25, TC2010, doi: 10.1029/2005TC001854.

MouthereAU, F. \& LACOMBE, O. 2006. Inversion of the Paleogene Chinese continental margin and thick-skinned deformation in the Western Foreland of Taiwan. Journal of Structural Geology 28, 1977-93.

Mouthereau, F., WatTS, A. B. \& Burov, E. 2013. Structure of orogenic belts controlled by lithosphere age. Nature Geoscience 6, 785-9.

Mpodozis, C. \& Ramos, V. A. 1989. The Andes of Chile and Argentina. In Geology of the Andes and its Relation to Hydrocarbon and Mineral Resources (eds G. E. Ericksen, M. T. Cañas Pinochet \& J. A. Reinemund), pp. 59-90. Circum-Pacific Council for Energy and Mineral Resources Earth Science Series 11. Houston, Texas:
Circum-Pacific Council for Energy and Mineral Resources Earth Science.

Müller, J. P., Kley, J. \& Jacobshagen, V. 2002. Structure and Cenozoic kinematics of the Eastern Cordillera, southern Bolivia $\left(21^{\circ} \mathrm{S}\right)$. Tectonics 21, 1037, doi: 10.1029/2001TC001340.

Myers, S., Beck, S., Zandt, G. \& Wallace, T. 1998. Lithospheric-scale structure across the Bolivian Andes from tomographic images of velocity and attenuation for $\mathrm{P}$ and S waves. Journal of Geophysical Research 103, 21233-52.

Newell, N. D. 1949. Geology of the Lake Titicaca region, Peru and Bolivia. Geological Society of America Memoir no. 36, $111 \mathrm{pp}$.

Noble, D. C., Silberman, M. L., MéGard, F. \& Bowman, H. R. 1978. Comendite (peralkaline rhyolites) in the Mitu Group, central Peru: evidence of Permian-Triassic extension in the Central Andes. U.S. Geological Survey Journal of Research 6, 453-7.

OncKen, O., Hindle, D., Kley, J., Elger, K., Victor, P. \& SCHEMANN, K. 2006. Deformation of the Central Andean upper plate system - facts, fiction, and constraints for plateau models. In The Andes: Active Subduction Orogeny (eds O. Oncken, G. Chong, G. Franz, P. Giese, H.-J. Gotze, V. A. Ramos, M. R. Strecker \& P. Wigger ), pp. 3-28. Berlin, Heidelberg: Springer-Verlag.

PARSEP. 2000. The Huallaga Basin and Adjacent Area: The Hydrocarbon Potential of NE Peru Huallaga, Santiago and Marañón Basins Study. Technical report: Proyecto de Asistencia para La Reglamentación del Sector Energético del Perú

Pearson, D. M., Kapp, P., DeCelles, P. G., Reiners, P. W., Gehrels, G. E., Ducea, M. N. \& Pullen, A. 2013. Influence of pre-Andean crustal structure on Cenozoic thrust belt kinematics and shortening magnitude: Northwestern Argentina. Geosphere 9, 1766-82.

PereZ, N. D. \& HorTon, B. K. 2014. Oligocene-Miocene deformational and depositional history of the Andean hinterland basin in the northern Altiplano plateau, southern Peru. Tectonics 33, 1819-47.

Pingel, H., Strecker, M. R., Alonso, R. N. \& Schmitt, A. K. 2013. Neotectonic basin and landscape evolution in the Eastern Cordillera of NW Argentina, Humahuaca Basin $\left(\sim 24^{\circ} \mathrm{S}\right)$. Basin Research 25, 554-73.

PRICE, R. A. 1981. The Cordilleran foreland thrust and fold belt in the southern Canadian Rocky Mountains. In Thrust and Nappe Tectonics (eds K. McClay \& N. J. Price), pp. 427-48. Geological Society of London, Special Publication no. 9.

RAmoS, V. A. 2000. The southern central Andes. In Tectonic Evolution of South America: 31st International Geological Congress, Rio de Janeiro, Brazil (eds U. G. Cordani, E. J. Milani, A. Thomaz Filho \& D. A. Campos), pp. 561-604.

Ramos, V. A. 2009. Anatomy and global context of the Andes: main geologic features and the Andean orogenic cycle. In Backbone of the Americas: Shallow Subduction, Plateau Uplift, and Ridge and Terrane Collision (eds S. M. Kay, V. A. Ramos \& W. R. Dickinson), pp. 31-65. Geological Society of America Memoir no. 204.

Ramos, V. A., Cegarra, M. \& CRISTAllini, E. 1996. Cenozoic tectonics of the High Andes of west-central Argentina (30-36 $6^{\circ}$ latitude). Tectonophysics 259, 185-200.

RAMOS, V. A., ZAPATA, T., CRISTALLINI, E. \& INTROCASO, A. 2004. The Andean thrust system - latitudinal variations in structural styles and orogenic shortening. In Thrust Tectonics and Hydrocarbon Systems (ed. K. R. McClay), 
pp. 30-50. American Association of Petroleum Geologists Memoir no. 82.

Reimann, C. R., BAhlburG, H., KoOIJMan, E., Berndt, J., Gerdes, A., Carlotto, V. \& Lopez, S. 2010. Geodynamic evolution of the early Paleozoic Western Gondwana margin $14^{\circ}-17^{\circ} \mathrm{S}$ reflected by the detritus of the Devonian and Ordovician basins of southern Peru and northern Bolivia. Gondwana Research 18, 370-84.

Reimann Zumsprekel, C. R., BAHLBURG, H., CARLOTto, V., Boekhout, F., BerndT, J. \& LoPeZ, S. 2015. Multimethod provenance model for early Paleozoic sedimentary basins of southern Peru and northern Bolivia (13 ${ }^{\circ}$ $\left.18^{\circ} \mathrm{S}\right)$. Journal of South American Earth Sciences 64, 94-115.

ReItSma, M. J. 2012. Reconstructing the Late Paleozoic : early Mesozoic plutonic and sedimentary record of south-east Peru: orphaned back-arcs along the western margin of Gondwana. Thèse de doctorat, Université de Genève, Genève, Switzerland. no. Sc. 4459. Published thesis.

REINERS, P. W. 2005. Zircon(U-Th)/He thermochronometry. Reviews in Mineralogy and Geochemistry 58, 151-79.

Restrepo-Pace, P. A., Ruiz, J., Gehrels, G. \& Cosca, M. 1997. Geochronology and Nd isotopic data of Grenvilleage rocks in the Colombian Andes: new constraints for late Proterozoic Early Paleozoic paleocontinental reconstructions of the Americas. Earth and Planetary Science Letters 150, 427-41.

RILLER, U. \& ONCKEN, O. 2003. Growth of the central Andean Plateau by tectonic segmentation is controlled by the gradient in crustal shortening. Journal of Geology 111, 367-84.

Rodriguez, R., Flores, T. \& MArocco, R. 1999. Analisis sedimentologico y estratigrafico de la Formacion Tinajani (Cenozoico del Altiplano del Sur del Peru). Aportes a la reconstruccion de la evolucion tectono-sedimentaria del Sur del Peru entre el Oligoceno superior y el Mioceno superior. Boletin de la Sociedad Geológica del Perú 89 , $33-44$.

RoEDER, D. 1988. Andean-age structure of Eastern Cordillera (province of La Paz, Bolivia). Tectonics 7, 23-39.

Roeder, D. \& Chamberlain, R. L. 1995. Structural geology of sub-Andean fold and thrust belt in northwestern Bolivia. In Petroleum Basins of South America (eds A. J. Tankard, R. Suárez Soruco \& H. J. Welsink), pp. 459-79. American Association of Petroleum Geologists Memoir no. 62.

Roperch, P., Sempere, T., Macedo, O., Arriagada, C., FORNARI, M., TAPIA, C., GARCIA, M. \& LAJ, C. 2006. Counterclockwise rotation of late Eocene-Oligocene fore-arc deposits in southern Peru and its significance for oroclinal bending in the central Andes. Tectonics 25, TC3010, doi: 10.1029/2005TC001882.

Rosas, S., Fontbote, L. \& TANKARD, A. 2007. Tectonic evolution and paleogeography of the Mesozoic Pucara Basin, central Peru. Journal of South American Earth Sciences 24, 1-24.

Rousse, S., Gilder, S., Fornari, M. \& Sempere, T. 2005. Insight into the Neogene tectonic history of the northern Bolivian Orocline from new paleomagnetic and geochronologic data. Tectonics 24, TC6007, doi: 10.1029/2004TC001760.

Sagripanti, L., Bottesi, G., KietzMann, D., Folguera, A. \& RAMOS, V. A. 2012. Mountain building processes at the orogenic front: a study of the unroofing in Neogene foreland sequence $\left(37^{\circ} \mathrm{S}\right)$. Andean Geology 39, 201-19.

SANDEMAN, H. A., Clark, A. H. \& FARRAR, E. 1995. An integrated tectono-magmatic model for the evolution of the Southern Peruvian Andes $\left(13-20^{\circ} \mathrm{S}\right)$ since $55 \mathrm{Ma}$. International Geology Reviews 37, 1039-73.

Sandeman, H. A., Clark, A. H. Farrar, E. \& Pauca, G. A. 1997. Lithostratigraphy, petrology and ${ }^{40} \mathrm{Ar}-{ }^{39} \mathrm{Ar}$ geochronology of the Crucero Supergroup, Puno Department, SE Peru. Journal of South American Earth Sciences 10, 223-45.

SAYLOR, J. E. \& HoRTON, B. K. 2014. Nonuniform surface uplift of the Andean plateau revealed by deuterium isotopes in Miocene volcanic glass from southern Peru. Earth and Planetary Science Letters 387, 120 31.

SAYlor, J. E., Horton, B. K., Stockli, D. E., MorA, A. \& CORREDOR, J. 2012. Structural and thermochronological evidence for Paleogene basement-involved shortening in the axial Eastern Cordillera, Colombia. Journal of South American Earth Sciences 39, 202-15.

ScherrenberG, A. F., Holcombe, R. J. \& Rosenbaum, G. 2014. The persistence and role of basin structures on the 3D architecture of Cross Mark the Maranon Fold-Thrust Belt, Peru. Journal of South American Earth Sciences 51, $45-58$.

ScherrenberG, A. F., JacaY, J., Holcombe, R. J. \& RosENBAUM, G. 2012. Stratigraphic variations across the Marañon Fold-Thrust Belt, Peru: implications for the basin architecture of the West Peruvian Trough. Journal of South American Earth Sciences 38, 147-58.

SCHILDGEN, T. F., Ehlers, T. A., WhiPP, D. M., VAN Soest, M. C., Whipple, K. X. \& Hodges, K. V. 2009. Quantifying canyon incision and Andean Plateau surface uplift, southwest Peru: a thermochronometer and numerical modeling approach. Journal of Geophysical Research-Earth Surface 114, F04014, doi: 10.1029/2009JF001305.

Schildgen, T. F., Hodges, K. V., Whipple, K. X., ReIners, P. W. \& Pringle, M. S. 2007. Uplift of the western margin of the Andean plateau revealed from canyon incision history, southern Peru. Geology 35, 523-6.

SCHMitz, M. 1994. A balanced model of the southern Central Andes Tectonics 13, 484-92.

Sempere, T., Carlier, G., Soler, P., Fornari, M., CARlotTo, V., JacAY, J., ARISPe, O., NÉraUdeaU, D., CÁrdenas, J., Rosas, S. \& Jiménez, N. 2002. Late Permian-Middle Jurassic lithospheric thinning in Peru and Bolivia, and its bearing on Andean-age tectonics. Tectonophysics 345, 153-81.

Sempere, T., Herail, G., Oller, J. \& Bonhomme, M. G. 1990. Late Oligocene early Miocene major tectonic crisis and related basins in Bolivia. Geology 18, 946-9.

SHEFFELS, B. M. 1990. Lower bound on the amount of crustal shortening in the central Bolivian Andes. Geology 18, $812-5$.

SiBSON, R. H. 1985. A note on fault reactivation. Journal of Structural Geology 7, 751-4.

SIBSON, R. H. 1990. Rupture nucleation on unfavorably oriented faults. Bulletin of the Seismological Society of America 80, 1580-604.

SIKS, B. C. \& HORTON, B. K. 2011. Growth and fragmentation of the Andean foreland basin during eastward advance of fold-thrust deformation, Puna plateau and Eastern Cordillera, northern Argentina. Tectonics 30, TC6017, doi: 10.1029/2011TC002944.

Strecker, M. R., Alonso, R., BoOKhagen, B., CARrapa, B., Coutand, I., Hain, M. P., Hilley, G. E., Mortimer, E., Schoenbohm, L. \& Sobel, E. R. 2009. Does the topographic distribution of the central Andean Puna Plateau result from climatic or geodynamic processes? Geology 37, 643-6. 
Strecker, M. R., Alonso, R. N., Bookhagen, B., Carrapa, B., Hilley, G. E., Sobel, E. R. \& Trauth, M. H. 2007. Tectonics and climate of the southern central Andes. Annual Review of Earth and Planetary Sciences 35, 747-87.

TAssinari, C. C. G., Bettencourt, J. S., Geraldes, M. C., MACAMBIRA, M. J. B. \& LAFON, J. M. 2000. The Amazon Craton. In Tectonic Evolution of South America: 31st International Geological Congress, Rio de Janeiro, Brazil (eds U. G. Cordani, E. J. Milani, A. M. Thomaz Filho \& D. A. Campos), pp. 41-95.

TeIXell, A., ArboleyA, M. L., Julivert, M. \& Charroud, M. 2003. Tectonic shortening and topography in the central High Atlas (Morocco). Tectonics 22, 1051, doi: 10.1029/2002TC001460.

VICENTE, J.-C. 1990. Early Late Cretaceous overthrusting in the Western Cordillera of Southern Peru. In Geology of the Andes and its Relation to Hydrocarbon and Mineral Resources (eds G. E. Ericksen, M. T. Cañas Pinochet \& J. A. Reinemund), pp. 91-117. Circum-Pacific Council for Energy and Mineral Resources Earth Science Series 11. Houston, Texas: Circum-Pacific Council for Energy and Mineral Resources Earth Science.

Watts, A. B., Lamb, S. H., Fairhead, J. D. \& Dewey, J. F. 1995. Lithospheric flexure and bending of the Central Andes. Earth and Planetary Science Letters 134, 9-21.

WhIPPLE, K. X. \& GASPARINI, N. M. 2014. Tectonic control of topography, rainfall patterns, and erosion during rapid post-12 Ma uplift of the Bolivian Andes. Lithosphere 6, 251-68.

Whitman, D., Isacks, B. L., Chatelain, J. L., ChiU, J. M. \& PEREZ, A. 1992. Attenuation of high-frequency seismic-waves beneath the Central Andean plateau. Journal of Geophysical Research-Solid Earth 97, 19929-47.

WHITMAN, D., ISACKS, B. L. \& KAY, S. M. 1996. Lithospheric structure and along-strike segmentation of the Central Andean Plateau: seismic Q, magmatism, flexure, topography and tectonics. Tectonophysics 259, 29-40.

Wigger, P., Schmitz, M., ARANEDA, M., Asch, G., Baldzuhn, S., Giese, P., Geinsohn, W. D., Martinez, F., RiCALDI, E., ROWER, P. \& VIRAMONTE, J. 1994. Variation of the crustal structure of the southern Central Andes deduced from seismic refraction investigations. In Tectonics of the Southern Central Andes (eds K.-J. Reutter, E. Scheuber \& P. J. Wigger), pp. 23-48. New York: Springer-Verlag.

Williams, G. D., Powell, C. M. \& CoOper, M. A. 1989. Geometry and kinematics of inversion tectonics. In Inversion Tectonics (eds M. A. Cooper \& G. D. Williams), pp. 3-15. Geological Society of London, Special Publication no. 44.

WILSON, J. J. 1963. Cretaceous stratigraphy of Central Andes of Peru. American Association of Petroleum Geologists Bulletin 47, 1-34.

WoOdWARD, N., BOYER, S. E. \& SupPe, J. 1989. Balanced Geological Cross-Sections: An Essential Technique in Geological Research and Exploration. Short Courses in Geology, vol. 6. Washington, DC: American Geophysical Union.

ZAPATA, T. R. \& ALlMENDINGER, R. W. 1996. Thrust-front zone of the Precordillera, Argentina: a thick-skinned triangle zone. American Association of Petroleum Geologists Bulletin 80, 359-81. 